\title{
Bridging Innate and Adaptive Antitumor Immunity Targeting Glycans
}

\author{
Anastas Pashov, ${ }^{1}$ Bejatolah Monzavi-Karbassi, ${ }^{1}$ Gajendra P. S. Raghava, ${ }^{2}$ \\ and Thomas Kieber-Emmons ${ }^{1}$ \\ ${ }^{1}$ Department of Pathology, Winthrop P. Rockefeller Cancer Institute, University of Arkansas for Medical Sciences,
4301 West Markham St., Slot no.824, Little Rock, AR 72205, USA
${ }^{2}$ Bioinformatics Centre, Institute of Microbial Technology, Sector 39A, Chandigarh 160036, India
}

Correspondence should be addressed to Thomas Kieber-Emmons, tke@uams.edu

Received 26 January 2010; Accepted 22 April 2010

Academic Editor: Hanchun Yang

Copyright (C) 2010 Anastas Pashov et al. This is an open access article distributed under the Creative Commons Attribution License, which permits unrestricted use, distribution, and reproduction in any medium, provided the original work is properly cited.

\begin{abstract}
Effective immunotherapy for cancer depends on cellular responses to tumor antigens. The role of major histocompatibility complex (MHC) in T-cell recognition and T-cell receptor repertoire selection has become a central tenet in immunology. Structurally, this does not contradict earlier findings that T-cells can differentiate between small hapten structures like simple glycans. Understanding T-cell recognition of antigens as defined genetically by $\mathrm{MHC}$ and combinatorially by $\mathrm{T}$ cell receptors led to the "altered self" hypothesis. This notion reflects a more fundamental principle underlying immune surveillance and integrating evolutionarily and mechanistically diverse elements of the immune system. Danger associated molecular patterns, including those generated by glycan remodeling, represent an instance of altered self. A prominent example is the modification of the tumorassociated antigen MUC1. Similar examples emphasize glycan reactivity patterns of antigen receptors as a phenomenon bridging innate and adaptive but also humoral and cellular immunity and providing templates for immunotherapies.
\end{abstract}

\section{Introduction}

It is a widely held view that the engagement of both innate and adaptive cellular immune responses is necessary for efficient immunotherapy of cancer $[1,2]$. Using vastly different molecular and cellular strategies, they operate in concert targeting tumor antigens [3-5] albeit cancer cells escape this immune surveillance via a variety of mechanisms $[6,7]$. Consequently, in contrast to the long-held belief that most cancers are weakly immunogenic [8], antitumor immune surveillance mechanisms prove much more prevalent. The observation of naturally occurring tumor reactive $B[9,10]$ and $T$ lymphocytes [11-15] along with tumor reactive innate immune cells that include natural killer (NK) cells, granulocytes, and macrophages, raises hopes that immunotherapy may succeed in targeted patients, specifically those with either regional or minimal residual disease and in the preventive setting [16-20].

While tumor cells are not usually in the focus of the immune system, Burnet and Thomas hypothesized that the immune system can recognize nascent transformed cells and can eliminate primary tumor formation [21]. The process of immune editing validates the operative nature of immune surveillance, suggesting that at some point antitumor immune surveillance was working and that immune editing is a form of escape from immune surveillance. Such observations also lead to the hypothesis that downstream suppressive mechanisms may dominate antitumor immune responses, permitting malignant cells to evade an effectively primed immune response. As we come to understand immune surveillance mechanisms better, these mechanisms should prove a useful template for immunotherapy design, but also instructing on which patient populations might benefit the most from immunotherapy approaches. Immune surveillance, as a model and rationale for immunotherapy, requires that cancer cells are recognized as "nonself" or may be "perturbation of self." Often the ability of inducing a rejection strength response has been associated with appearance of xenoantigenic determinants but now the other dimension of immunogenicity-the danger signal [22] is recognized as even more important. 
Natural immunity is the first actor on stage in immune surveillance processes, with polyspecific IgM antibodies, typically reactive with "xenotypic" or "neotypic" carbohydrate antigens, playing a role in surveillance $[9,23]$. Antitumor immunity mediated by naturally occurring antibodies was first noticed in mice [23]. Naturally occurring antibodies to Tumor-Associated Carbohydrate Antigens (TACAs) are observed in cancer patients and are attributed to patient longevity $[9,24]$. Whether the B cells producing these antibodies, coupled with $\mathrm{T}$ cells, represent an inducible component of cancer immunosurveillance-and one that might be therapeutically exploited-remains unknown. Tumor reactive activated $\mathrm{B}$ cells can collaborate with effector $\mathrm{T}$ cells in adoptive cellular therapies of cancer. Activated B cells can be used as effective antigen presenting cells (APCs) for T cell sensitization. In this context tumor-primed B cells might collaborate with effector $\mathrm{T}$ cells in adoptive cellular therapies of cancer. Other B cell subsets (Bregs, IL-10 producing, etc.) may rather impair $\mathrm{T}$ cell responses.

Unlike the clonally organized adaptive immunity, the cells in the innate system bind to nonself determinants quasispecifically, using pattern-recognition receptors. A prominent antigen type that fits this bill are carbohydrates. Due to dysregulation of glycoslyation events, carbohydrates are often altered and/or overexpressed as multivalent molecular species [25] on the tumor cell surface, possibly representing a type of danger signal [22] to the immune system. In fact the Gal (Gal $\alpha 1-3 \mathrm{Gal})$ antigen, is the major target of preexisting antibodies in tissue rejection in xenotransplantation [26] validating carbohydrates as targets for tissue rejection and carbohydrate expression patterns as danger signals. These xenoreactive natural antibodies comprise $1 \%$ of circulating IgG. Furthermore, anti-Gal antibodies can be exploited for clinical use in cancer immunotherapy by targeting autologous tumor vaccines engineered to express the Gal antigen to APC, thereby increasing vaccine immunogenicity [26].

In this paper, focus is placed upon the role carbohydrate binding receptors and cells expressing them play in bridging innate and adaptive immune responses to cancer cells. Carbohydrate antigens are targets of the immune surveillance machinery and these responses provide a template for cancer immunotherapy. Of particular importance is how carbohydrate reactive lymphocytes and cells of the innate immunity might mediate cellular responses. This includes the role glycopeptides and carbohydrate mimetic peptides might play in integrating innate and adaptive antitumor responses. Certain peptides act as molecular mimics of carbohydrates in that carbohydrate-binding proteins specifically recognize them but may also activate tumor reactive $\mathrm{T}$ cells [27-29]. Naturally occurring carbohydrate mimics include peptide regions from MUC1 [30]. Carbohydrate mimetic peptides as mimics of glycopeptides, glycoproteins, and carbohydrate structures provide an interesting bridge to facilitate B and $\mathrm{T}$ cell interactions. While making for vaccine candidates, they also provide a tool to probe carbohydrate immunology paradigms because the synergistic interaction of effector $\mathrm{T}$ and B cells require common recognition of identical tumorassociated antigen(s).

\section{Carbohydrates and the Immune Surveillance Paradigm}

The success of vaccines in infectious disease prevention, together with the evidence for immune control over tumor growth, are major arguments in favor of immunotherapy or cancer vaccine approaches. Although the main processes involved in these two aspects of immunity are mostly the same, the context is different. A major difference between microbial pathogens and tumors as potential vaccine targets is that cancer cells are derived from the host, and express mostly self-antigens present in normal cells. In terms of antigenic properties and "danger" signals, an infection is an external perturbation followed by a reaction to it as the system is returning to its previous or very close equilibrium. Cancer, for its part, is a gradual transformation of the very equilibrium state of the system. It can be seen as a disease of "selfish" tissue proliferation that causes pathological immune tolerance as its own provision. Now it is clear that the difference between self and nonself is defined by a complex set of tolerance mechanisms beyond the absence of antigen specific reactivity. Understanding tolerance as active, threshold-dependent, and redundant helps rationalize its reshaping and repair, rather than breaking, as a tumor immunotherapy objective [31].

The task of designing immunotherapies that can effectively impact on the survival of cancer patients remains challenging. Two important elements in this challenge are defining antigenic formulations that target multiple antigens associated with tumor cells [31], and to understand the therapeutically effective range (frequency) of effector cells for antitumor protection [14, 32]. Sugars display high density on tumor cells and often play a critical role in immune recognition [33-37]. In addition, often times they are neoantigens as many are embryonic in nature. As suggested recently, it's the antigen stupid [20], one needs not look beyond carbohydrate targets, because TACAs prove to be broad-spectrum antigens or "universal tumor antigen" targets for immune surveillance $[9,31]$ by antibodies, cells of the innate immune system and lymphocytes. Despite clinical evidence for glycoantigens as important cancer targets they are still largely neglected. Notes of caution come mostly in the context of low immunogenicity of carbohydrates and their dual role as "danger" or immune suppressive signals [38]. Nevertheless, sufficient body of evidence indicates that the unique immunomics of tumor-associated glycoantigens may yield clinically important biomarkers and treatment targets for the management of human cancer [39].

Adaptive immune responses have long been considered the territory of antigenic proteins because they are $\mathrm{T}$ cell dependent (TD), whereas carbohydrates are characterized as T-cell-independent (TI) (either Type 1 or Type 2) antigens [40]. Typically, adaptive responses depend on the recognition of protein sequences by $\mathrm{T}$ helper (Th) cells. In addition, thymus-independent responses may be related to a more or less sequestered compartment of the antibody repertoire $[41,42]$. Yet, T cells reactive with processed glycopeptides as well as glycolipids have been described [43]. The running paradigm is that albeit CD1 presentation to NKT cells is 
possible [44], pure carbohydrate forms are believed not to be associated with $\mathrm{T}$ cell presentation. Nevertheless, some types of carbohydrates are processed and presented to $\mathrm{T}$ cells by class II MHC $[45,46]$. Carbohydrate antigens displaying helical shapes [47], which mimic helical peptides, are suggested to bind directly to at least the MHC Class II grove, indicating that carbohydrate antigens devoid of lipids and protein can directly influence $\mathrm{T}$ cell proliferation [48]. Model carbohydrates with a zwitterionic structure appear to affect $\mathrm{T}$ cell activation, being responsible in preventing abscesses induced by pathogenic bacteria [49]. Taken together, these advances illustrate an indisputable viewpoint that carbohydrate recognition by the adaptive and innate immune system is an indispensable stage of most immune responses.

The induction of an effective response to tumors mainly depends on innate and adaptive immunity coordinated by Dendritic Cells (DCs). DCs in particular are well equipped to distinguish between self- and nonself-antigens by the invariable cell-surface receptors such as C-type lectin receptors (CLRs) and Toll-like receptors (TLRs). CLRs are adept at recognizing glycoproteins in general, while typical pattern recognition receptors, such as TLRs, detect various molecular patterns typical only for microbial antigens. Uptake of antigen by CLRs leads to presentation on MHC class I and II molecules. It is likely that the crosstalk between TLRs and CLRs, differentially expressed by subsets of DCs, account for the different pathways to peripheral tolerance, such as deletion and suppression, and immune activation [38]. Several pathogens specifically target CLRs to subvert this communication to escape immune surveillance, either by inducing tolerance or skewing the protective immune responses [50]. It is likely that tumor cells do the same as they adapt their glycan shield to immune effector cells.

Lessons can be learned from immune surveillance mechanisms associated with natural antibodies. Apes, old world monkeys, and humans do not express the Gal epitope on their tissues, and therefore have circulating life-termgenerated anti-Gal antibodies due to antigenic stimulation by bacteria of gastrointestinal flora $[51,52]$. Human anti-Gal antibodies are of IgM and IgG isotypes [51, 53, 54]. AntiGal antibodies responsible for hyperacute rejection of pig-toprimate xenotransplantation are mostly IgM and apparently work through a complement dependent mechanism. If the hyperacute rejection is prevented, after a delay an acute vascular rejection will occur, in which $\operatorname{IgG}$ antibodies play a major role $[55,56]$. All $\operatorname{IgG}$ subclasses are present in the postimmune serum [56] and rejection is dependent on complement and Fc receptor [57]. Therefore, as expected, exposure to the respective antigen will trigger a secondary response mostly of specifically induced and cross-reactive IgG.

Anti-Gal antibodies are purported to augment the uptake and presentation of tumor antigens by antigen-presenting cells to induce higher immune responses $[58,59]$. This uptake mechanism might relate to TACAs as well. Two TACAs that are highly thought of as immune targets are the Thomsen-Friedenreich (TF or T) antigen (Galb13GalNAca) and the Tn (GalNAca) antigens [60]. Human

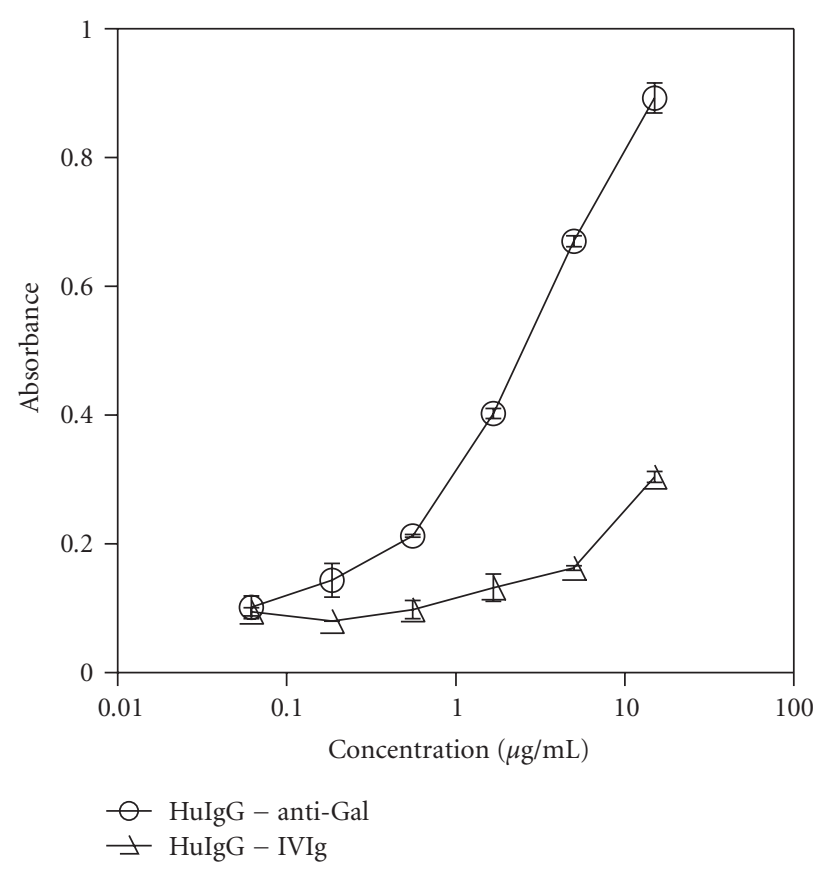

Figure 1: A. ELISA plates were coated with blood type B antigen and reactivity of Gal purified human antibodies detected. Human IVIg was used as control.

blood serum contains natural TF- and Tn antibodies whose subpopulations may bind the corresponding antigens on human tumor cell lines [61, 62]. The high level of anti-TF and $\mathrm{Tn}$ IgG, observed in some patients with cancer, may be a sign of an ongoing immune response, as indicated by the switching of antibody to the IgG-class. They may be also cross-reactive antibodies raised to other structurally similar carbohydrate forms. Blood Group B individuals, for example, may show reactivity to Tn antigen [63], and some anti-Gal antibodies are cross-reactive with the Blood Group $B$ antigen [64] and Figure 1.

A high level of anti-TF and Tn antibody titers in longterm cancer survivors are supportive of the idea that patients with a disease of an early stage or with a minimal residue are more responsive to active immunotherapy $[65,66]$. The detectable spontaneous immune responses to TF and Tn antigens are not necessarily efficient since the expression of these antigens correlates with worse prognosis mostly because of increased metastasis [67]. The reason may be an escape from the control by immune responses to TACA like TF, Tn, and sialyl-Tn enforced by the biological function of these antigens, since immunoediting would select cells that suppress the expression of TACA. It is also possible that the correlation with higher grade and metastasis is due to the observation only of these tumors that have been resistant to immunoediting and, respectively, the lowered malignancy of the immunoedited tumors. It would be interesting to differentiate between primarily TACA negative tumors and secondarily negative due to immunediting. It is likely that specific suppressive influence of the tumor on the production of TF antibodies is associated with the stage and grade of the 
tumor. The observation of positive correlation between the level of TF antibodies and the count of lymphocytes in TFresponders appears to reflect the adaptive immune response and provides a further explanation for the involvement of anti-TF IgG in cancer-associated immunosuppression. However, the possible protective mechanism of TF antibodies in cancer has yet remained unclear as is the role antibodies play in the natural anticancer defense system.

\section{T Cells and Glycans}

The paradigm of $\mathrm{T}$ cell recognition of foreign antigens is principally established by studies of the host immune response to proteins and peptides. However, the demonstration that $\mathrm{T}$ cells can recognize nonprotein antigens has modified ideas on the chemical nature of molecules recognized by $\mathrm{T}$ cells [68]. In the early years, it was suggested that hapten-specific $\mathrm{T}$ cells recognize haptenmodified peptides [69]. Chemical haptens and metal ions interact with proteins and thereby become recognizable by $\mathrm{T}$ and $\mathrm{B}$ lymphocytes. At the same time, they induce the production of proinflammatory cytokines and chemokines by various cell types due to triggering of innate immune responses. This is an important prerequisite for the activation of the adaptive immune system and the development of diseases like allergic contact dermatitis and adverse drug and autoimmune reactions. But they may also provide concepts relevant for immunotherapy of cancers, as hapten model systems are not that dissimilar to peptides modified with small carbohydrate antigens. Hapten-specific $\mathrm{T}$ cells can detect antigenic structures in two ways. They can recognize the hapten only in context with a specific amino acid motif or independent of the carrier peptide.

In the last decade, a number of researchers report that both $\mathrm{CD}^{+}$and $\mathrm{CD}^{+}{ }^{+} \mathrm{T}$ cells can recognize glycopeptides carrying mono- and disaccharides in a MHC-restricted manner, provided the glycan group is attached to the peptide at suitable positions [70-82]. For such glycopeptides, the primed $\mathrm{T}$ cells recognize the glycan structure with high fidelity. These observations are very important in understanding the complexity of the antitumor response targets especially in terms of abnormal expression.

Due to an incomplete formation of glycan sidechains resulting from premature glycosylation events, the restrictive distribution of short glycans such as the TF, Tn, and sialyl Tn (NeuAca2-6GalNAca) in normal tissues and their extensive expression in a variety of epithelial cancers make them excellent targets for immunotherapy. Immunodominant glycopeptide remnant epitopes as well as glycosylation changes on self-proteins can generate antitumor responses. For example, anti-sTn Thelper type 1 (Th1) antigen-specific T-cell response as determined by interferon- $\gamma$, has been noted in patients immunized with a sialyl-Tn-conjugate [83].

The carbohydrate-based design for $\mathrm{T}$ cell antigens is strongly supported by several HLA/peptide complexes resolved by crystallography $[74,80]$. The structure of different crystals describes the core of the peptide(s), as critical for TCR recognition with a "cavity" corresponding to the CDR3 region that often accommodates aromatic amino acid residues, similar in size and conformation to small glycan molecules, as TF, or the monomer Tn. The ability of TACA-specific $\mathrm{T}$ cell clones to recognize glycan antigens in the context of different peptide sequences is very relevant to validate this imunotherapeutic approach. The ability of $\mathrm{T}$ cells to recognize mono-and disaccharides attached to peptides with Ser or Thr might indicate that $\mathrm{T}$ cells might be degenerate in recognizing glycopeptides (Table 1). In some cases CTL, generated upon immunization with glycopetide, preferentially kill target cells treated with glycopeptide compared to those treated with the core peptide. In other cases it does not matter [81], and in some cases it has been suggested that other glycan receptors are involved in T cell targeting [84]. Polyclonal CTL have been observed to kill target cells expressing glycolipid [43]. It has been suggested that glycopeptide-specific-restricted CTL and unrestricted glycan-specific CTL belong to different $\mathrm{T}$ cell populations with regard to TCR expression [70]. Such results demonstrate that hapten-specific unrestricted CTL responses can be generated with MHC class I-binding carrier peptides.

The development of designer glycopepitdes based upon high affinity binding to MHC Class I or Class II is an acceptable practice for enhancing $\mathrm{T}$ cell responses [72, 82, 85]. The design of such glycopeptides usually starts with some concept of a target sequence and then modifying it based upon amino acid substitution guided by some sense of change in binding affinity of the peptide core for MHC. Central to these peptides is a Ser or Thr at position 46 to which a glycan antigen is attached (Table 1). While promiscuous MHC binders are possibly the optimal carriers for the carbohydrate epitopes, it is not clear where to choose potential peptide cores from. The use of epitopes from widespread viruses, like influenza virus, may not be the best solution. Instead of providing a recall immune response, such peptide cores may be recognized by virus specific $\mathrm{T}$ cells as altered peptide ligands and actually prevent the immune response. Another adverse phenomenon that can be anticipated in this case is original antigenic sin.

An alternative to glycopeptides are carbohydrate mimetic peptides (CMP), which are non-glycoslyated but can induce $\mathrm{T}$ cells reactive with glycopeptides or induce $\mathrm{T}$ cells that are MHC unrestricted. CMPs function as xenoantigens and, consequently, can overcome tolerance to carbohydrate selfantigens. CMPs from natural proteins are known for some time. Peptides from MUC1 are shown to be naturally occurring CMPs [30, 86-89]. In particular, MUC1 derived peptides are considered mimics of the Gal-epitope $[86,89]$. In our own studies CMPs, as defined by cross-reactivity to TACA reactive antibodies and lectins, induce Thl responses [90] and antitumor $\mathrm{CD}^{+} \mathrm{T}$ cells [91]. Molecular modeling studies indicate that amino acids can themselves be structurally similar to mono-and disaccharides on glycopeptides [29]. CMP reactive T cells can also be activated by the TACA that they mimic [90]. Unlike unconjugated carbohydrate antigens, we have shown that unconjugated multivalent antigen peptide forms of CMPs prime for subsequent memory of unconjugated carbohydrate antigens, facilitating longterm surveillance through recall of carbohydrate immune 
TABLE 1

\begin{tabular}{|c|c|c|c|c|c|c|c|}
\hline \multirow{2}{*}{ MHC Alleles } & \multirow{2}{*}{ Total Binders } & \multicolumn{3}{|c|}{ Binders having Ser at Position } & \multicolumn{3}{|c|}{ Binders having Thr at Position } \\
\hline & & 4 & 5 & 6 & 4 & 5 & 6 \\
\hline HLA-A $* 0201$ & 1497 & 92 & 64 & 87 & 62 & 81 & 66 \\
\hline $\mathrm{H} 2-\mathrm{B}$ & 16 & 1 & 0 & 2 & 0 & 1 & 0 \\
\hline $\mathrm{H} 2-\mathrm{D}$ & 92 & 4 & 5 & 7 & 3 & 2 & 2 \\
\hline $\mathrm{H} 2-\mathrm{Db}$ & 249 & 28 & 12 & 19 & 10 & 5 & 10 \\
\hline $\mathrm{H} 2-\mathrm{Kb}$ & 319 & 13 & 4 & 15 & 18 & 6 & 20 \\
\hline $\mathrm{H} 2-\mathrm{Kd}$ & 325 & 20 & 15 & 9 & 14 & 18 & 20 \\
\hline HLA-A & 5325 & 268 & 265 & 414 & 170 & 272 & 252 \\
\hline HLA-B & 2963 & 150 & 178 & 283 & 170 & 141 & 126 \\
\hline
\end{tabular}

responses [92]. This effect is a major advantage that would minimize the need for constant boosting. Furthermore, we observed that CMPs mediate cognate $\mathrm{B}$ and $\mathrm{T}$ cell interactions as CMPs can induce antibodies in a host model with deficiency in IgM production that typically do not respond to carbohydrate antigens [93]. These studies stress the role of B cells as APCs as part of the CMP effect in vivo. Particular B cell subsets may affect differentially tumor reactive $\mathrm{T}$ cell involvement in this process. More importantly, the type of TACA mimicked by the CMPs are expressed in mice. Consequently, these studies are obtained in a toleragenic model, further suggesting that tolerance is broken upon CMP immunization.

\section{Bridging the Divide between TACA Reactivity and $\mathrm{CD4}^{+} \mathrm{T}$ Cells}

Tumor immunotherapy with nonmutated tumor-associated antigens attempts to break tolerance in a manner reminiscent of models for autoimmune diseases. When autoimmune diseases are induced in animal models, they are often selflimiting, which is rarely the case with spontaneous autoimmune pathology. It may be possible to use a similar model of induced autoimmune inflammation as a strategy for an effective tumor immunotherapy since cancer patients in general are not genetically prone to autoimmunity. Although it has been expected and conceptually implicated in different approaches, this notion was directly addressed only recently [94]. The dissection of tumor immunity indicates roles for $\mathrm{B}$ and $\mathrm{T}$ lymphocytes that include $\mathrm{CD} 4^{+} \mathrm{T}$ cell responses of the T-helper type-1 (Th1) phenotype [95]. There is adequate evidence to prove a central role of the $\mathrm{CD} 4^{+} \mathrm{T}$ cell in antitumor immunity [96-98]. This is possible through direct communication between the tumor cell and $\mathrm{CD} 4^{+}$ $\mathrm{T}$ cell through interferon gamma (IFN $\gamma)$, IFN $\gamma$ receptor interactions or through tumor stroma interactions [97].

Delayed Type Hypersensitivity (DTH) reactions are a means to monitor $\mathrm{CD} 4^{+} \mathrm{T}$ cell responses to the immunizing agent and in some cases DTH responses in cancer patients correlate with survival. It has been postulated that the Th1 cell is the "inducer" of a DTH response since it secretes IFN $\gamma$, while the T-helper type-1 (Th2) cell is either not involved or acting as a downregulator of the cell mediated immune response [99]. Although typically inducing $\mathrm{T}$ cell independent responses, surprisingly, some carbohydrate targeting vaccines have induced also DTH responses in humans [100102].

Early studies using xenogenized cells suggest that the mechanisms of antiparental tumor protection involve specific induction of a DTH response mediated by the inflammatory Th1 subset of L3T4+ T lymphocytes and IFNactivated macrophages [103]. Tumor cells can mediate DTH responses, necessary for tumor regression [104]. Typically, at the time of immunization, DTH-effector T cells are activated by binding to complexes of antigen peptides and MHC molecules on APCs. Subsequently, at skin challenge with antigen, DTH is elicited involving at some point recruitment of antigen specific memory $\mathrm{T}$ cells into the tissues and recognition of $\mathrm{Ag} /$ peptide-MHC complexes on presenting cells. This leads to a characteristic late 24- to 48-hours effector responses.

The earliest events in DTH have only recently been shown to depend on B-1 B cell produced IgM, immune complexes and complement [105]. B-1 cell-derived antihapten IgM antibodies generated within 1 day (d) of immunization combine with local challenge antigen to activate complement and recruit $\mathrm{T}$ cells [106]. These latter findings overturn three widely accepted immune response paradigms by showing that (a) specific IgM antibodies are required to initiate contact sensitivity (CS), which is a classical model of $\mathrm{T}$ cell immunity thought exclusively due to $\mathrm{T}$ cells, (b) CS priming induces production of specific IgM antibodies within $1 \mathrm{~d}$, although primary antibody responses typically begin by day 4 , and (c) B-1 cells produce the $1-\mathrm{d}$ IgM response to CS priming, initiating the DTH response, while B cells are generally considered suppressive in tumor immunity due to their production of IL-10 [107]. Finally, these findings indicate a possible mechanistic scenario for interaction between anticarbohydrate and Th1 responses.

As clinical correlates have highlighted carbohydrate reactive IgM responses to cancer cells in humans [24, 108], attention to antibody subsets is warranted to further understand and develop strategies to augment these responses, which might further impact on tumor reactive 
cellular responses. Natural polyreactive antibodies that bind to tumor cells have been studied on several occasions. They are germline encoded antibodies mostly from $\mathrm{CD}^{+}$ $B$ cells (the B1 genotype), they bind to various tumor antigens, induce apoptosis of tumor cells and detect not only malignant cells but also the precursor stages [10]. Natural polyreactive IgM autoantibodies, encoded by unmutated germline Ig V genes, represent a major fraction of the normal circulating IgM repertoire [109]. Such antibodies fulfill the definition of autoantibodies as they are self-reactive but they have broad reactivity and bind mostly to altered antigens. Even in mouse models, nonimmunized mice of widely differing genetic backgrounds have detectable IgM antibodies to tumor cell surface carbohydrates, their natural resistance to this tumor being related to their serum levels [110].

Because B1 cells can strongly activate $\mathrm{T}$ cells and induce Th1 cell differentiation by antigen presentation [111], we have been testing for CMP mediated $\mathrm{T}$ cell responses. Although cognate, MHC-restricted interaction of Th cells with antigen-presenting $B$ cells provides effective help to a resting B cell, substantial B cell responses are also observed with preactivated $\mathrm{T}$ cell clones in a noncognate fashion (bystander help without specific Ag recognition) [112]. We have recently shown that immunization of mice with a carbohydrate mimetic peptide reactive with GD2 reactive antibodies induce GD2 reactive IgM antibodies [113]. This CMP also induces a DTH response to GD2 positive D142.34 cells, while no response was observed against the GD2 negative expressing cell line B78.H1 [114]. Consequently, our results on DTH induction can be interpreted in the following way. The anti-GD2 IgM induced by CMP plays the role of an initiating factor for a DTH response perpetuated by $\mathrm{T}$ cells cross-reactive with CMP and an unknown antigen on the tumor cells line, which have been stimulated during the priming with CMP.

This observation suggests that the dual character of a CMP carrying $\mathrm{T}$ cell epitopes, but also mimicking an unrelated TI-2 carbohydrate epitope, provides for long term IgM responses by promoting other aspects of cooperation between particular B cell subpopulations and CMP specific $\mathrm{T}$ cells reminiscent of epitope spreading [115]. One concept is that cognate interactions occur because the CMP is presented by MHC Class II on the B cell, stimulating concomitant peptide reactive $T$ cells [28]. It is interesting to note that a very recent study by Deola et al. found another mechanism for noncognate $\mathrm{T}$ cell2-B cell interaction involved in the propagation of CTL longevity [116] and dependent on CD27. This antigen is considered a marker of human memory B cells. It is expressed also on human peripheral IgM "memory" cells that are related to marginal zone B cells. In their study, Deola et al. also demonstrate that the T-B contact initiates a chemotactic mechanism for a targeted serial noncognate T-B cell contacts. Such an intensive interaction in the absence of specific antigen recognition may be a prerequisite for a much more important role for $\mathrm{T}$ cell derived signals to bystander B cells.

The highly protective antibody responses mounted particularly by B1 cells clearly indicate a crucial role for this subset of B cells in TACA-targeting immunotherapy, but targeting B1 cells may actually skew Th1 responses for any antigen [111] which is highly desirable in antitumor cell response. DTH responses require both $\mathrm{B} 1$ and $\mathrm{CD} 4^{+} \mathrm{T}$-cell cognate recognition [117]. Precisely establishing the role of B1 cells in this respect relates not only to a possible longterm IgM response but, more importantly, circumventing a possible involvement of $\mathrm{CD} 1 \mathrm{~d}^{\text {hi }} \mathrm{CD}^{+}$Bregs (B10 cells) [118].

These observations further suggest that we pay more attention to the role of the major B cell subpopulations, and that carbohydrate reactive IgM antibodies in particular may help to bridge cellular responses. Expanding the pool of memory $\mathrm{B}$ and $\mathrm{T}$ cells by $\mathrm{CMP}$ vaccination or to activate residual TACA memory $\mathrm{B}$ and $\mathrm{T}$ cells might be of benefit for the course of immunization. Multivalent CMPs target B1 cells, which are hypothesized to facilitate the Th1 responses observed with the CMPs [93]. Collectively, these observations suggest that targeting the "natural memory" B cell repertoire might provide novel mechanisms to prevent recurrence of disease mediated through $\mathrm{CD}^{+} \mathrm{T}$ cell responses. Although the mechanisms by which immunological memory is maintained after infection or vaccination are related to TD responses [119], similar mechanisms may also apply to cancer vaccines that target TACAs. Therefore, we hypothesize that CMP's immunotherapeutic potential is related to their capacity to stimulate B cell compartments that bridge innate and adaptive immunity. The translational character of the proposed mechanisms depends on the specifics of the human immune system. The central issue in this respect is the identity and physiology of the B cell subpopulation(s) that best relate CMP specificity to Th1 stimulation with potential to expand an epitope-spreading cascade. The human equivalents of mouse B1a, B1b and MZ $\mathrm{B}$ cells are still to be identified, if at all possible.

Another major mechanism involving B cells, along with other antigen presenting cells, in the initiation of adaptive responses is the formation of immune complexes including by natural antibodies. A number of possible mechanisms of immune complex modulatory role have been proposed (reviewed in [120]) including the central event of immune complex retention by follicular DCs [121]. An essential feature of antibodies in this respect is the isotype distribution. It affects the involvement of different $\mathrm{Fc}$ and complement receptors and the subsequent functional effects. Among them of special interest in tumor immunotheray is antigen crosspresentation.

\section{TACA Mediated Crosspresentation That Activates Cellular Responses}

Much has been learned about the maze of signaling events and cast of molecular characters activating cellular responses, principally by studying antigen trafficking. In broad strokes, antigenic peptides are presented to cytotoxic $\mathrm{T}\left(\mathrm{CD}^{+}\right)$and $\mathrm{T}$ helper $\left(\mathrm{CD}^{+}\right)$cells by two separate pathways-intracellular (originating in the cytoplasm, in complex with MHC class I) and extracellular (after internalization, in complex with 
MHC class II). The same $\mathrm{T}$ cell signaling machinery picks between peptides presented in MHC class I or class II, guided by the TCR specificity and with the help of the coreceptors CD8 or CD4 [122]. The two processes, though, serve quite different roles. The economy of the solution goes further as the same type of pAPC serve as initiators, licensing the $\mathrm{T}$ cell response in both cases. Utilizing the same or very similar cellular and molecular mechanisms by both pathways necessitates that pAPC are susceptible to infection with any intracellular parasite or, alternatively, that the external pathway intersects or mimics sometimes the internal. The fact that CTL responses can be mounted to those rare viruses that do not infect pAPC is a key argument in favor of the interaction between the two pathways [123], or, as it has been branded, crosspresentation [124].

After acquiring antigen by the external pathway, crosspresenting pAPC can activate or cross-prime naïve $\mathrm{CD} 8^{+}$ $\mathrm{T}$ cells with respective specificity initiating CTL responses not only to viruses but also to subunit [125] and DNA vaccines $[126,127]$ and tumor cell derived antigens [128130]. The crosspresentation of self -antigens, for example, from phagocytosed apoptotic cells including tumor cells, may play also a role in cross-tolerization of autoreactive $\mathrm{CD} 8^{+} \mathrm{T}$ cells in the periphery [131-133].

The concept of crosspresentation has not been accepted without some resistance $[134,135]$. Still, as long as interrupting Th responses due to pAPC killing by CTL is avoided, cross-priming is compatible with current views and unavoidable in the explanation of some immune phenomena. Understanding the observed CTL responses to tumor specific antigens [136-141] as well as the induction of CTL responses to tumors by appropriate vaccines [139, 142, 143] relies heavily on presenting of external antigens in class I. The hypothetical suppressive effect on other $\mathrm{T}$ cell responses due to killing of pAPC can be avoided, at least to some extent, by specialization of a particular subset of pAPC [144].

For carbohydrate antigens, crosspresentation can make use of $\mathrm{CD} 1$ or pattern recognition receptors. Antigen presenting cells interact with antigens through an array of pattern recognition receptors (PRR-mostly wide range of C-type lectins-CLR, TLRs, etc.) as well as through complexes with antibodies and complement utilizing Fcy and complement receptors. All of these capture mechanisms lead to internalization and presentation in class II. Most pathways of antigen internalization by DC were considered potentially permissive also of crosspresentation. Many were proven to be so.

The cross-presenting immature mouse DC express a wide range of CLRs from type IV and type II [145]. Type IV CLRs include type I transmembrane proteins with multiple carbohydrate recognition domains (CRD) like CD205 (DEC205) with still unknown specificity and CD206 that binds terminal mannose [146]. Expressed preferentially on $\mathrm{CD} 8^{+}$ DC, CD205 acts as a recognition receptor for dying cells, potentially providing an important pathway for the uptake of self-antigen in central and peripheral tolerance [147]. Its ligand specificity is still unknown. The mannose binding CD206 may be exclusively involved in the internalization and crosspresentation of soluble antigens [148]. Consequently, mannose has been used as a delivery vector for antigens in vaccine design $[149,150]$ and has been considered in terms of undesirable immunogenicity [151]. Some ligands of CD206 trigger the DC expressing it to respond with an anti-inflammatory immunosuppressive cytokine pattern [152].

Type II CLRs are also known as asialoglycoprotein receptor family. Among its members role in crosspresentation has been found for CD207 and CD209 (DC-DSIGN) $[153,154]$ recognizing broad set of sugars including fucose, mannose, $\mathrm{N}$-acetylglucosamine, and sulfated sugars [155158]. Another member of this family is dectin-1. Its primary pathogen associated pattern is $\beta$-glucan [159]. The pathogen recognition is usually in conjunction with TLR2 and TLR4 triggering [160] to yield either proinflammatory cytokine secretion when phagocytosis is hindered or immunosuppressive signal when the bound particles are internalized [161, 162]. This context helps interpret the meaning of the finding that dectin-1 participates in the uptake of cellular antigens by human monocyte-derived DC and the cross-tolerization to the antigens associated [163]. Another member of this family, which is structurally related to dectin-1, is DNGR-1 (CLEC9A) - a novel, highly specific marker of mouse and human DC subsets that can be exploited for CTL crosspriming and tumor therapy [164]. Like dectin-1 and CD205, it has been found expressed on CD8 ${ }^{+}$mouse DC and it binds and internalizes for loading on class I apoptotic cell antigens [165]. Like CD205, its, so far unknown, intracellular ligand is protease sensitive $[147,165]$.

Thus, although most of the known CLR appear capable of mediating crosspresentation, the outcome is, as a rule, tolerogenic DC phenotype [166]. It seems that the signals are interpreted in terms of the coengagement of appropriate TLR receptors, which not only switch on the cross-presenting function for some of the CLRs, but also modify the immune context of $\mathrm{T}$ cell stimulation [33], for example, to immunogenic.

CLRs are a part of a general scavenging mechanism. The same receptors, that do the first rough sorting of dangerous nonself, recognize also out of place "self" as an equally dangerous signal. Several examples like CD205 and dectin-1 indicate that there may be a general overlap of the PRR for pathogen associated molecular patterns (PAMPs) and receptors of apoptotic cells as well as those for danger-associated molecular patterns (DAMPs). Common structural themes shape in this broad recognition processes. crosspresentation is associated with carbohydrate epitopes for the extracellular PAMPs and hydrophobic regions for both PAMPs and DAMPs. Another common feature is the polyspecificity of these interactions captured in the term "patterns". Polyspecificity is a basis for a functional mimicry, which in this case is not in the sense of a switched signal but in the context of converging signals from a class of ligands conveying common biological meaning [167]. The overlap of carbohydrate and intracellular hydrophobic binding sites may suggest a biological function of carbohydrate/protein mimicry-a structural marker of changes in the internal environment. 


\section{Antibody Mediated Crosspresentation}

The most intrinsic immune component participating in crosspresentation not so much as an input signal, but more as a feedback, are the antigen specific antibodies. At some point in the infectious cycle, most intracellular pathogens reside in the extracellular space, where they are vulnerable to antibody action. Thus formed immune complexes target them to Fc receptors the crosslinking of which can have profound effects both as signal transduction in the APC as well as presentation pathway of viral antigens $[168,169]$. The formation of immune complexes is the fundamental basis of using the Gal epitope to facilitate vaccine development [143]. Although $\mathrm{CD}^{+}$DCs constitutively cross-present exogenous antigens in the context of MHC class I molecules, $\mathrm{CD}^{-}$DCs are actually also capable of doing so after activation via crosslinking of Fc $\gamma$ Rs [170]. It was shown that crosspresentation of tumor antigens after capturing through Fc $\gamma \mathrm{R}$ on DC is much more efficient than after internalization of dead cells or loading with peptide [171]. The increased presentation was not due to enhanced tumor cell uptake or to DC maturation. Recent results with NYESO-1 peptide further reinforced the evidence for a key role of antibodies in tumor immunity through providing for crosspresentation to CTL [130]. These examples stressed the importance of raising specific humoral responses to tumors, but in antiviral responses even natural antibodies are found to mediate presentation to CTL [172]. Autoantibodies, on the other hand, are also found to contribute to autoimmunity promoting self-reactivity in CTL [132].

Since they are represented mostly by IgM isotype, natural antibodies effect is dependent on complement deposition in the immune complexes and complement receptors [173]. The highly efficient crosspresentation of antigen in immune complexes containing IgG [174] seems to depend on Fc $\gamma$ RIIA, which, unlike CLRs, is not downregulated in the process of maturation [175]. In immature DC this pathway is actually counterbalanced by the inhibitory Fc $\gamma$ RIIB whose levels diminish in the process of maturation and, somewhat counter intuitively, mature DC cross-present through the $\mathrm{F} c \gamma \mathrm{R}$ pathway better than iDC [175]. It has been proposed that an enhancement of antitumor immunity may by possible by transient blockade of FcgRIIB [176]. The high efficiency of CTL priming by immune complexes has implications both for the design of tumor vaccines and for the mechanism of action of monoclonal antibodies used in immunotherapy. In the mouse system the hierarchy of the activity of the IgG isotypes of a class switched antitumor antibody was found to be IgG2a $\geq \operatorname{IgG} 2 \mathrm{~b}>\operatorname{IgG} 1 \gg \operatorname{IgG} 3$ and this followed the ratio of their affinity with the preferred activating FcR (Fc $\gamma$ RIII for IgG1, Fc $\gamma$ RIV for IgG2a and IgG2b) relative to the affinity with the inhibitory Fc $\gamma$ RIIB [177].

In humans, IgG1 and IgG3 have higher affinity for the FcRs than IgG2 and especially IgG4. In addition, there are allelic variants of activating Fc-receptors that will significantly change the affinity for certain antibody isotypes. Fc $\gamma$ RIIIA allele that contains a valine in position 158 (Fc $\gamma$ RIIIA158V) has a higher affinity for IgG1 and IgG3 than the receptor that has phenylalanine (Fc $\gamma$ RIIIA158F) at that position [176]. Furthermore, Fc $\gamma$ RIIA131H has a histidine at position 131 and a higher affinity for IgG2 than the 131R allele, which contains an arginine at the same position. This allelic polymorphism defines different efficiency of the antibody mediated crosspresentation and may warrant genetic testing for targeting the most responsive group of patients when immunotherapy is planned.

It is interesting to speculate in this context on the possible role of TACA reactive antibodies in tumor immunotherapy. As thymus independent antigens they induce mostly IgM and IgG3 (IgG2 in humans). Nevertheless, as for natural antibodies in viral infections, TI-2 responses seemingly affect cellular responses significantly. In animal tumor models, some TACA targeting immunizations yielded cellular responses to the tumor $[91,178]$. Although in the report by Wierbicki et al. the authors consider cross-reactivity of the carbohydrate mimotope peptide used with a peptide from CD166, the results are not conclusive. It is possible that in these cases the anti-TACA antibodies induced crosspresentation of tumor antigens associated with the TACA epitopes and, thus, initiated an epitope spreading loop. Further studies are necessary to determine the immunotherapeutic potential of this approach and its possible optimization, for example,in terms of suppression of the inhibitory Fc $\gamma$ Rs or therapeutic application of class switched TACA monoclonals. Furthermore, due to the low reactivity with the other FcR, the polymorphism in Fc $\gamma$ RIIA in humans would have a very strong impact on the effects of IgG2 antibodies. It is also interesting to speculate that sometimes targeting of the antigen to sizeable B cell populations leads to a very efficient immunization for all branches of the adaptive immune response. Although historically only activated B cells are known to present efficiently to naïve $\mathrm{T}$ cells as opposed to resting $B$ cells, recently it became clear that this rule should be mapped on to the $B$ cell population landscape where it is modified [111]. Furthermore, targeting of antigen to CD19 appears as particularly efficient in tapping the B cell APC properties, apparently with little dependence on the B cell functional state. In the case of MUC1, such targeting leads to an efficient breaking of self-tolerance and priming of both Th and CTL responses [179]. Elegant as it is, this strategy relies on an epiphenomenon, distantly reminding one of superantigen action. It is interesting to establish the degree of equivalence of this targeting technique to antigen specific internalization by BCR. Another technical detail is the apparent blocking of FcR interactions by the bulky protein attached that would normally occur in the case of immune complexes.

The targeting of different B cell populations may expand the potential to control the outcome of immunization and may be a mechanism contributing to the observed diverse effects of carriers on the immunogenicity of haptens. As self-antigens induce tolerance, vaccination with nonself antigens that molecularly mimic self-antigens may overcome tolerance and lead to generation of antitumor immune responses. Crosspresentation mediated by antibodies may be implicated in the insufficiently understood phenomena following immunization with carbohydrate mimicking peptides. Anti-MUC1 responses may offer an interesting model 
in this context. MUC1 is a highly glycosylated type I transmembrane glycoprotein with a unique extracellular domain consisting of a variable number of tandem repeats (VNTR) of 20 amino acids (PDTRPAPGSTAPPAHGVTSA). Antibodies and T-cell recognizing MUC1 antigens have been isolated from the blood of breast cancer patients [180, 181]. Using peptide vaccination anti-MUC1 antibodies were induced in mice [182]. Mimicry can occur also naturally, although the frequency of this phenomenon is still unknown. It was demonstrated that Gal $\alpha 1-3 \mathrm{Gal} \beta 1-4 \mathrm{GlcNAc}-\mathrm{R}$ (Gal epitope) and peptides derived from MUC1 antigen cross-react with anti-Gal antibodies [89]. Based on the immunogen and the immunization regimen and the background IgG isotype, the cross-reaction may lead to the production of certain IgG isotypes that can actually determine the vaccination outcome and the type of the immune responses. This concept suggests that there are two ways for presentation of peptides upon peptide immunization to facilitate cellular responses. The first follows extracellular loading onto Class II, the second through immune complexes formed with antibodies, with the efficiency of loading dependent on the isotype.

In a series of manuscripts McKenzie's group showed that anti-Gal antibodies reacted with MUC1 antigens and that anti-MUC1 antibodies reacted with Gal sugar. According to McKenzie's group previous publications on Gal crossreactivity, again suggests that a low titer carbohydrate crossreactive antibody is functional to protect patients from recurrence of the disease. So what evidence exists that crosspresentation might be operative? On the one hand anti-Gal antibodies are cross-reactive with MUC1 derived peptides. Figure 2 illustrates that human anti-Gal antibody is crossreactive with a MUC1 derived peptide with the sequence NH2-CPAHGVTSAPDTRPAPGSTAP (MAP format) relative to pooled human IgG (IVIg). The MUC1 peptide is also cross-reactive with the lectins jacalin (JAC), and Peanut agglutinin (PNA) (Figure 3) associated with binding of TACAs expressed on a variety of tumor cells $[183,184]$. JAC and PNA share as their preferred ligand the TF antigen, but differ in their finer specificities for modifications of this determinant and in their specificities for cancerous epithelia. In this context the MUC1 derived peptide is a CMP that mimics both the Gal epitope and TF antigen. While antibodies to MUC1 occur naturally in both healthy subjects and cancer patients it is difficult to ascertain their origin; for example, if anti-MUC1 antibodies are initially anti-TF or (most probably) anti-Gal antibodies.

The specificity of natural and induced MUC1 antibodies has defined minimal epitopic sequences, indicating that antibodies directed to more than one region of the MUC1 peptide core can coexist in one and the same subject. The most frequent minimal epitopic sequence of natural MUC1 IgG and IgM antibodies is found to be RPAPGS, followed by PPAHGVT and PDTRP. In some studies, MUC1 peptide vaccination induced high titers of IgM and IgG antibodies predominantly directed, respectively, to the PDTRPAP and the STAPPAHGV sequences of the tandem repeat. In recent studies we have identified a common crossreactivity with Gal antigen of P10s-a CMP mimicking GD2 (WRYTAPVHLGDG), and an immunodominant epitope of

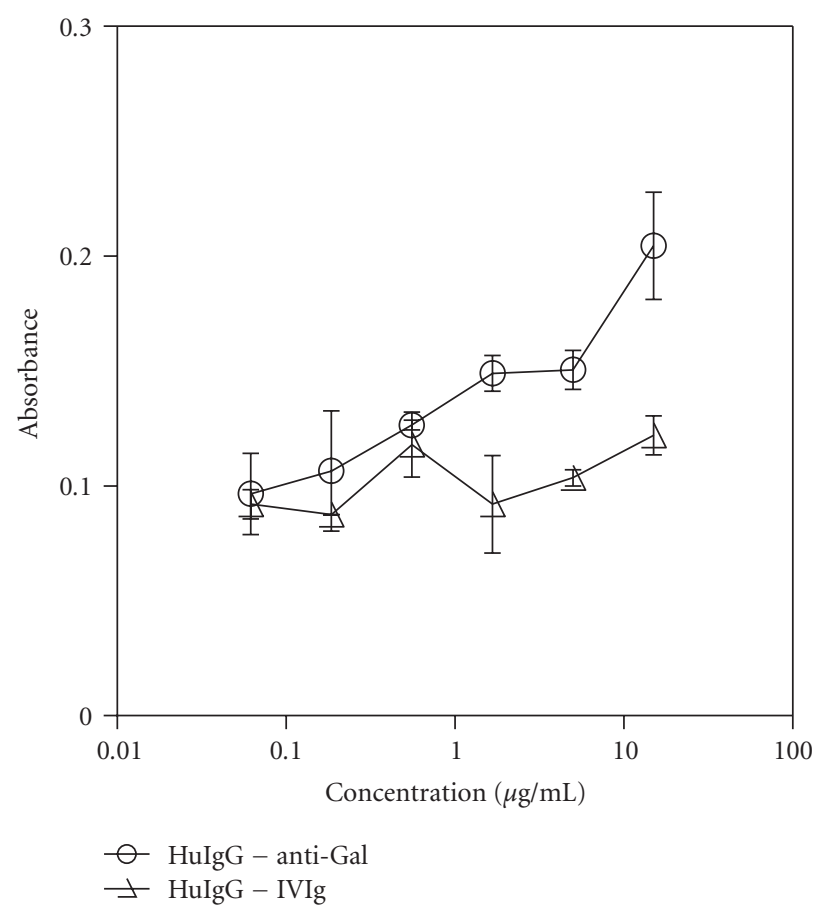

FIGURE 2: Plates were coated with MUC1 peptide and reactivity of human anti-Gal antibodies were measured. Human IVIg was used as negative control.

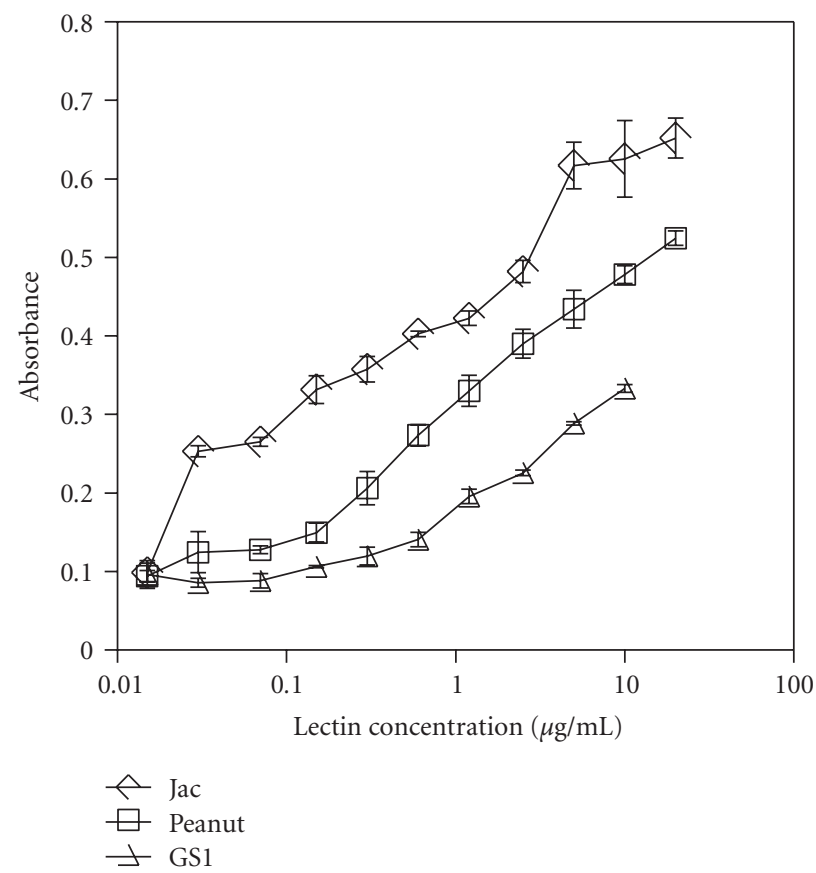

FIGURE 3: ELISA plates were coated with MUC1 peptide. Wells were then blocked with blocking buffer (PBS $+\mathrm{Ca} / \mathrm{Mg}$ and $1 \% \mathrm{BSA})$ and various concentrations of Lectins were added. Plates were incubated for two hours washed and binding was visualized by StreptavidinHRP. 


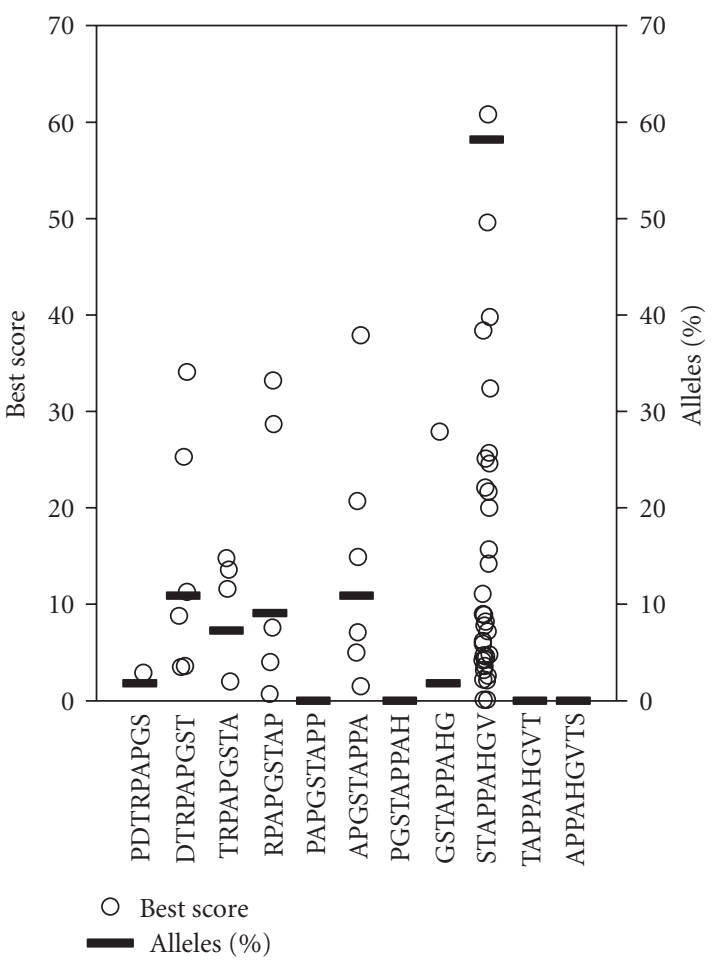

(a)

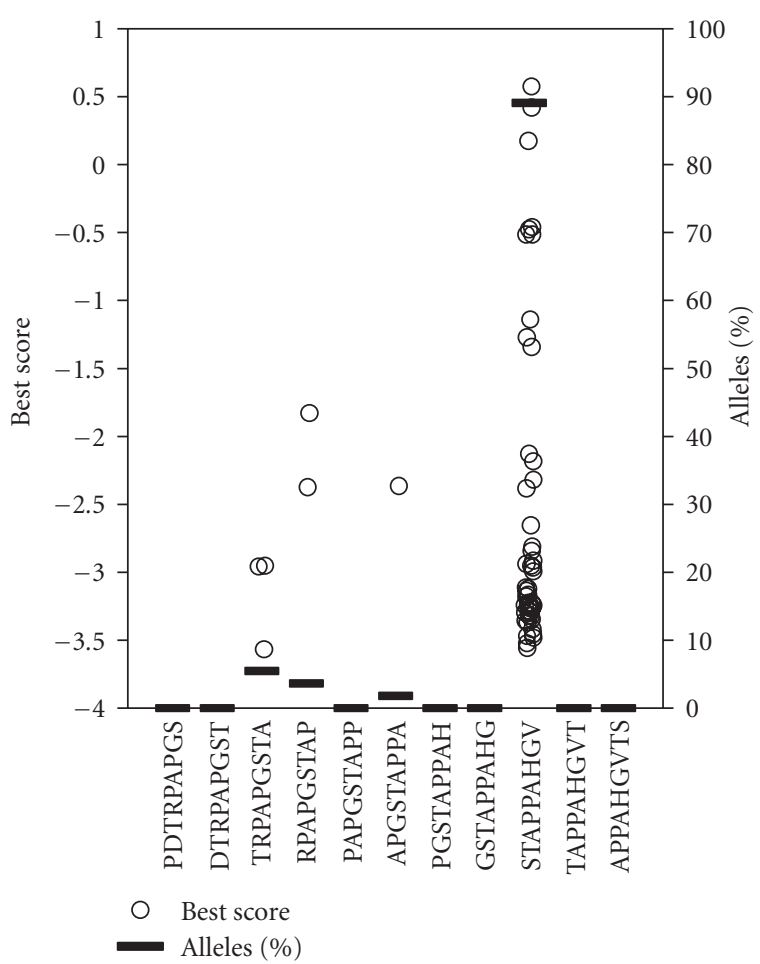

(b)

FIGURE 4: Using the Immune Database and Analysis Resource (IEDB, http://www.immuneepitope.org/) [187] the possible CTL epitopes in the sequence of the tandem repeat PDTRPAPGSTAPPAHGVTS were predicted. (a) Using consensus score only the best sequences for each allele are marked together with their score as well as the percentage of MHC class I alleles (secondary axis) for which the respective sequence is the best scoring sequence in the tandem repeat (the lower score indicates stronger binding); (b) A combined score using the ann algorithm for MHC calss I binding prediction, TAP transport and proteasome cleavage prediction is shown. The presentation is similar to (a). Again only the best-scoring sequences for each allele are shown. The higher scores indicate higher probability of presentation.

MUC1 (STAPPAHGVTS). Interestingly the peptides display compositional similarity as well as an alanine-proline dipeptide known to mimic structurally different sugar epitopes. We also observe that P10s is bound by antibodies that crossreact with $\mathrm{TF}$ and the $\mathrm{Tn}$ antigens. In this context, one could argue that the P10s CMP might be an antigenic "analog" of the STAPPAHGVTS sequence and further suggest that the TF and Tn mimicry of MUC1 lies within the STAPPAHGVTS sequence. In fact, the STAPPAHGV peptide has been defined as a CTL reactive peptide sequence $[66,185]$.

In mice, MUC1 peptide immunization resulted in cellular responses with reported little humoral response [86, 185]. In this context, it can be rationalized that peptide immunization resulted in activating cellular responses typical of peptide loading pathways. In contrast, MUC1 peptide induced strong cellular response in mice transformed to a strong antibody response in human immunization. It was argued that preexisting anti-Gal antibodies caused a deviation of the immune response in humans compared with mice that do not have anti-Gal antibodies [86]; attributed to cross-reactivity of natural anti-Gal antibodies to MUC1. It was shown that the Gal-CMP can induce humoral responses in Gal knockout mice, emulating the human condition. McKenzie's group clearly showed that anti-Gal antibodies cross-reacted with a mannan conjugated MUC1 peptide fusion protein lead to little cellular response, but a huge anti-MUC1 antibody responses in research subjects. They argued that such an immune response is based on macrophage Fc receptor binding to the immune complex, leading to processing via the exogenous pathway; MHC class II presentation and stimulation of helper T cells and antibody production. In the absence of anti-Gal antibodies, mannan binds to mannose receptor on macrophages and goes through the class I presentation to stimulate $\mathrm{CD} 8^{+}$ cells.

An alternative explanation is based on the fact that the MUC1 peptide is a nonself antigen in the mouse system and the strong CTL epitopes it contains direct the immune response. In the human system there is a strong tolerance mechanism precluding CTL response. It is interesting why the antibody response is not similarly suppressed. This may be due to cross-reactivity with the Gal antigen since the abundant anti-Gal memory B cells should exist with lower requirements for stimulation [186]. Using the Immune Database and Analysis Resource (IEDB, http://www.immuneepitope.org/) [187] the possible CTL 
and Th epitopes in the sequence of the tandem repeat PDTRPAPGSTAPPAHGVTS were predicted. In this carbohydrate mimotope-like stretch of the MUC1 sequence there is no significant class II binder predicted, although some very antigenic regions are found after the tandem repeats, for example in the region of aa1040-1060 (data not shown). For CTL epitopes both a consensus algorithm for predicting the MHC affinity for multiple alleles [188] and a combined prediction of proteasome cleavage, TAP transport and MHC affinity [189] were applied to determine the relative antigenicity of all 9-amino acid frames within the tested sequence. In this way, not only the potential MHC affinity of each frame but also the probability for the generation of this epitope in vivo was predicted. The STAPPAHGV epitope was clearly the best binder and a promiscuous epitope (Figure 4(a)). When considering the proteasome processing and TAP transport, even stronger immunodominance of this epitope is predicted (Figure 4(b)). In the context of self, as in MUC1 expressed in humans, whether on tumor or normal cells, this finding may rather be indicative of an essential self-epitope inducing clone deletion, anergy or suppression. If this epitope is really visible to the immune system, it is possible that its dominance is not by chance, since evolution would have evaded otherwise similar self-target. It would be interesting to speculate that an aberrant glycosylation in this case may affect the recognition and deviate the specificity to nontolerized clones. In the case of MHC class II, similar promiscuous and strong binders among self antigens may represent targets of regulatory $\mathrm{T}$ cells $[190,191]$ provided the affinity is bellow a threshold that would actually promote central deletion of the high affinity clones.

So what are the consequences of this mimicry? On the one hand, reactivity with natural Gal antibodies would suggest that immune complexes will be formed and that they are taken up by macrophages and DCs, if the isotype of the complex lends to efficient uptake. In this context uptake would lend to activation of cellular responses if permitted by the tolerance mechanisms. If this was operative one could speculate that lactating women would have a skewed carbohydrate reactive repertoire that would also be cross-reactive with high molecular weight mucins because of their inherent mimicry of TF, Tn and milk sugars. In fact, this has been the observation. Anti-MUC1 IgG antibodies are increased in lactating women [192, 193]. However such studies do not differentiate between MUC1 specific versus anti-Gal cross-reactive antibodies. Their presence can either lead to phagocytosis of immune complexes of IgG1 with MUC1 domains lending to crosspresentation and reduced breast cancer risk or not if the predominate anticarbohydrate fraction is IgG2. It is also possible that IgG/IgM ratios can exacerbate the progression of disease.

These observations further highlight that the immune system has already taken advantage of glycan cross-reactivity to teach us that immune surveillance is operative in that selfvaccination, representative of anti-Gal antibody mediated crosspresentation of mucin antigens can lower the risk of cancer. We just need to learn to trust what we observe clinically, understand it and replicate it within the proper setting.

\section{Conclusion}

Immunotherapy represents a fourth-modality therapeutic approach against human neoplasms. It remains very attractive in light of the shortcomings of malignant tumor management by conventional surgical, radiation, and chemotherapies. The hope for immunotherapy in the context of vaccines is the notion that the immune system can mount a rejection strength response against neoplastically-transformed cells. Cancer vaccines are entering a new phase of enthusiasm. Part of this is recognizing when vaccines are most functional. In particular, therapeutic vaccines are not viable for large tumors but play a more important role in regulating micrometastases (i.e., adjuvant setting) with emphasis on prevention of recurrence of disease. It is perceived that in order to be effective, cancer vaccines must either break tolerance or activate a "cryptic" population of $\mathrm{T}$ cells that escaped tolerance by virtue of their low affinity for antigens expressed by the tumor.

The concept of vaccines cannot be transferred mechanistically from infectious diseases because cancer cells express mostly self-antigens. While an infection is a perturbation of an equilibrium, which is restored by the immune system, cancer is a gradual transformation of the very equilibrium involving the immune system. Therefore, exploiting immune surveillance mechanisms is a challenge to our understanding of tolerance as a system property. Focusing on advances in cellular and molecular immunology, ultimately the knowledge of tolerance/surveillance mechanisms will help develop strategies that effectively and safely augment antitumor responses.

Carbohydrate determinants, both as epitopes as well as higher order patterns, are among the most ubiquitous tumor associated antigenic targets. The clinical importance of targeting TACAs is highlighted by: (1) the success of carbohydrate-based vaccines against infectious diseases; (2) the role of TACAs in autoimmune phenomena and tissue rejection and (3) the beneficial clinical correlates observed in cancer patients with anti-TACA antibodies. The limitations of the anti-tumor response to them might prove to some extent subjective, that is, rather a limitation of our understanding of surveillance. Carbohydrate moieties can and do participate in CTL epitopes and represent targets for cytotoxicity. Anticarbohydrate responses potentially bridge innate and adaptive immunity, $\mathrm{T}$ cell dependent and independent responses, humoral and cellular mechanisms. Their potential to affect directly and indirectly antitumor responses is still poorly understood and underutilized. The higher orderstructures of TACA provide danger signals to the immune system recognizable by antibodies. Carbohydrate targets focus the activity of innate activating and tolerizing pattern recognition receptor together with antibodies (natural and induced) and, possibly, T cells. This is, at least, a prerequisite for an organizing role in tumor surveillance. However, we hypothesize that tolerance to TACA- conjugate vaccines is related to compartmentalization of the repertoires that generate TI responses to self or non-self carbohydrate antigens. One consequence of this hypothesis is that immunologic carriers in TACA-based vaccines may play another role besides 
recruiting $\mathrm{T}$ cell help. They may redirect or perhaps highjack the immunogen from one compartment to another which would negatively impact on their ability to induce the type of desired immune response. Carbohydrate-conjugate vaccines are inherently designed to induce Th2 responses, while most anti-tumor targeting concepts focus on Th1 responses.

In terms of future directions, the design of immunogens eliciting long-lasting anti-TACA IgM responses would greatly improve the therapeutic utility of TACA-targeted vaccines. In some respects, we have thrown the baby out with the bath water. IgM antibodies are typically dismissed as being effective. However, natural IgM antibodies prove effective as proapoptotic molecules as part of the immune surveillance. To generate sustained immunity to TACAs, we have developed immunogens based on CMPs - a strategy whose clinical promise is supported by our preliminary studies. Carbohydrate mimicking peptides are agents with a potential to address the essential role of carbohydrates in tumor surveillance, but their application would depend on a systemic view of their pharmacodynamics beyond the mechanistic concepts borrowed from pathogen vaccines.

We have observed that sustained low serum titers of antiTACA antibodies, elicited by CMP, are sufficient to inhibit the growth of tumors in therapeutic and prophylactic mouse models. Consequently, we might be barking up the wrong tree in developing high affinity responses. It is debatable if glycosylated $\mathrm{T}$ cell epitopes are better than naked peptide versions. It is clear that glycosylated peptide versions will be limited to loading onto dendritic cells and can not be incorporated into vector technologies. CMPs can be used in multiple formats. They induce cellular responses, including CMP- and TACA-reactive Th1 $\mathrm{CD}^{+}$and tumorspecific $\mathrm{CD}^{+}$cells. Most of all, CMPs can prime for memory responses to TACAs, which might be related to the B1b cell compartment. The relative specificity of mimics and the unusual dual immunological character (peptide epitopes/carbohydrate mimotopes) makes CMP novel tools to understand and manipulate immune responses to tumor cells. Thus, some, still enigmatic, immune effects of CMPs are definitely related to an organizing role in $\mathrm{T} / \mathrm{B} / \mathrm{NK}$ cell cooperation. These include: a role for anticarbohydrate responses in cross-priming, Th1 stimulation, DTH and NK antitumor activity, possibly through DC and B cell compartments that bridge innate and adaptive immunity.

A more fundament, set of studies are required to understand how the ratio of IgM to IgG might affect tumor progression. Augmentation of IgM titers to TACA are perceived to correlate with tumor growth inhibition while evidence is available that $\operatorname{IgG}$ might promote tumor progression. This might be of particular importance to better understand how carbohydrate reactive antibodies emerge in pregnant versus lactating women. But understanding these responses can provide insight as to how immune surveillance might be exploited in cancer vaccine design. Carbohydrate reactive antibodies and $\mathrm{T}$ cells may promote or prevent tumor growth by antigenic modulation or by cytotoxic killing of tumor cells. The emergence of IgM/IgG ratios may serve as a potential early endpoint for the effectiveness of cancer vaccines expressing TACA types.
TACAs might themselves associate with MHC. Molecular recognition is about the ordered arrangement of atoms and not on the molecular species. Consequently, helical carbohydrates might mimic helical peptides in associating with MHC Class II molecules or extended carbohydrates might mimic the beta structure type arrangement of peptides in the MHC Class I binding site. Interestingly, T cells that see carbohydrates or glycans might be unrestricted in that the $\mathrm{T}$ cell receptor might see antigen directly, devoid of MHC. Such $\mathrm{T}$ cells unfortunately might compete with antibodies for the same epitope. Such T cells are suggested to interact with MUC1 but have not been characterized. Yet such T cells could play an important role in immune surveillance.

The existence of cross-reactive antibodies to glycans suggests that cross-presentation might be operative for some antigens. More studies should be directed on the nature of cross-presentation of natural antibodies. IgG1 can theoretically cross present, but IgG2, which are typically thought of as carbohydrate reactive, might not. How does the ratio between these isotypes affect cross-presentation and how do natural polymorphisms of $\mathrm{Fc}$ receptors affect the outcome of cancer patients? Polymorphisms should be able to be exploited to improve vaccine efficacy. A better understanding of these mechanisms should contribute to designing MUC1 derived peptides to engage natural carbohydrate reactive antibodies to improve upon T cell targeting of MUC1.

Pattern recognition is fundamental to innate immune surveillance. These receptors typified by lectins, are "hardwired" in the germ line. The innate immune response not only provides a first line of defense against invading microbes but also instructs the adaptive immune response. The discovery of Toll-like receptors has influenced thinking on how the innate immune response affects adaptive immunity. Interestingly all of these pattern receptors like carbohydrate antigens but TACA are still understudied in cancer immunotherapy circles.

\section{Acknowledgment}

This work was supported by a Clinical Translational Award from the Department of Defense Breast Cancer Program (W81XWH-06-1-0542).

\section{References}

[1] D. Chaudhuri, R. Suriano, A. Mittelman, and R. K. Tiwari, "Targeting the immune system in cancer," Current Pharmaceutical Biotechnology, vol. 10, no. 2, pp. 166-184, 2009.

[2] N. Bhardwaj, "Harnessing the immune system to treat cancer," Journal of Clinical Investigation, vol. 117, no. 5, pp. 1130-1136, 2007.

[3] J. C. Sun and L. L. Lanier, "Natural killer cells remember: an evolutionary bridge between innate and adaptive immunity?" European Journal of Immunology, vol. 39, no. 8, pp. 2059-2064, 2009.

[4] D. H. Raulet, "Interplay of natural killer cells and their receptors with the adaptive immune response," Nature Immunology, vol. 5, no. 10, pp. 996-1002, 2004. 
[5] J. D. Bui and R. D. Schreiber, "Cancer immunosurveillance, immunoediting and inflammation: independent or interdependent processes?" Current Opinion in Immunology, vol. 19, no. 2, pp. 203-208, 2007.

[6] L. Zitvogel, A. Tesniere, and G. Kroemer, "Cancer despite immunosurveillance: immunoselection and immunosubversion," Nature Reviews Immunology, vol. 6, no. 10, pp. 715727, 2006.

[7] T. Boon and N. van Baren, "Immunosurveillance against cancer and immunotherapy-synergy or antagonism?" The New England Journal of Medicine, vol. 348, no. 3, pp. 252 254, 2003.

[8] A. F. Ochsenbein, P. Klenerman, U. Karrer, et al., "Immune surveillance against a solid tumor fails because of immunological ignorance," Proceedings of the National Academy of Sciences of the United States of America, vol. 96, no. 5, pp. 2233-2238, 1999.

[9] H. P. Vollmers and S. Brändlein, "Natural antibodies and cancer," New Biotechnology, vol. 25, no. 5, pp. 294-298, 2009.

[10] E. Toubi and Y. Shoenfeld, "Protective autoimmunity in cancer (review)," Oncology Reports, vol. 17, no. 1, pp. 245251, 2007.

[11] M. Dougan and G. Dranoff, "Immune therapy for cancer," Annual Review of Immunology, vol. 27, pp. 83-117, 2009.

[12] M. I. Nishimura, J. J. Roszkowski, T. V. Moore, N. Brasic, M. D. McKee, and T. M. Clay, "Antigen recognition and T-cell biology," Cancer Treatment and Research, vol. 123, pp. 37-59, 2005.

[13] T. Boon, P. G. Coulie, B. J. van den Eynde, and P. van der Bruggen, "Human T cell responses against melanoma," Annual Review of Immunology, vol. 24, pp. 175-208, 2006.

[14] M. L. Disis and K. H. Park, "Immunomodulation of breast cancer via tumor antigen specific Th1," Cancer Research and Treatment, vol. 41, no. 3, pp. 117-121, 2009.

[15] G. Dranoff, “Targets of protective tumor immunity," Annals of the New York Academy of Sciences, vol. 1174, pp. 74-80, 2009.

[16] A. Gray, A. B. Raff, M. Chiriva-Internati, S.-Y. Chen, and W. M. Kast, "A paradigm shift in therapeutic vaccination of cancer patients: the need to apply therapeutic vaccination strategies in the preventive setting," Immunological Reviews, vol. 222, no. 1, pp. 316-327, 2008.

[17] M. G. Carmichael, L. C. Benavides, J. P. Holmes, et al., "Results of the first phase 1 clinical trial of the HER-2/neu peptide (GP2) vaccine in disease-free breast cancer patients: United States Military Cancer Institute Clinical Trials Group Study I-04,” Cancer, vol. 116, no. 2, pp. 292-301, 2010.

[18] L. G. Salazar and M. L. Disis, "Cancer vaccines: the role of tumor burden in tipping the scale toward vaccine efficacy," Journal of Clinical Oncology, vol. 23, no. 30, pp. 7397-7398, 2005.

[19] A. E. Seif, D. M. Barrett, M. Milone, V. I. Brown, S. A. Grupp, and G. S. D. Reid, "Long-term protection from syngeneic acute lymphoblastic leukemia by CpG ODN-mediated stimulation of innate and adaptive immune responses," Blood, vol. 114, no. 12, pp. 2459-2466, 2009.

[20] M. R. Buckwalter and P. K. Srivastava, “"It is the antigen(s), stupid" and other lessons from over a decade of vaccitherapy of human cancer," Seminars in Immunology, vol. 20, no. 5, pp. 296-300, 2008.

[21] M. Burnet, "Cancer; a biological approach. I. The processes of control," British Medical Journal, vol. 1, no. 5022, pp. 779786, 1957.
[22] P. Matzinger, "The danger model: a renewed sense of self," Science, vol. 296, no. 5566, pp. 301-305, 2002.

[23] S. E. Martin and W. J. Martin, "Anti tumor antibodies in normal mouse sera," International Journal of Cancer, vol. 15, no. 4, pp. 658-664, 1975.

[24] T. Takahashi, T. D. Johnson, Y. Nishinaka, D. L. Morton, and R. F. Irie, "IgM anti-ganglioside antibodies induced by melanoma cell vaccine correlate with survival of melanoma patients," Journal of Investigative Dermatology, vol. 112, no. 2, pp. 205-209, 1999.

[25] F. Dair'Olio, "Protein glycosylation in cancer biology: an overview," Journal of Clinical Pathology, vol. 49, no. 3, pp. M126-M135, 1996.

[26] U. Galili, "The $\alpha$-gal epitope and the anti-Gal antibody in xenotransplantation and in cancer immunotherapy," Immunology and Cell Biology, vol. 83, no. 6, pp. 674-686, 2005.

[27] P. Luo, G. Canziani, G. Cunto-Amesty, and T. KieberEmmons, "A molecular basis for functional peptide mimicry of a carbohydrate antigen," Journal of Biological Chemistry, vol. 275, no. 21, pp. 16146-16154, 2000.

[28] G. Cunto-Amesty, T. K. Dam, P. Luo, et al., "Directing the immune response to carbohydrate antigens," Journal of Biological Chemistry, vol. 276, no. 32, pp. 30490-30498, 2001.

[29] B. Monzavi-Karbassi, G. Cunto-Amesty, P. Luo, and T. Kieber-Emmons, "Peptide mimotopes as surrogate antigens of carbohydrates in vaccine discovery," Trends in Biotechnology, vol. 20, no. 5, pp. 207-214, 2002.

[30] V. Apostolopoulos, M. S. Sandrin, and I. F. C. McKenzie, "Carbohydrate/peptide mimics: effect on MUC1 cancer immunotherapy," Journal of Molecular Medicine, vol. 77, no. 5, pp. 427-436, 1999.

[31] A. Pashov, B. Monzavi-Karbassi, M. Chow, M. Cannon, and T. Kieber-Emmons, "Immune surveillance as a rationale for immunotherapy?" Human Vaccines, vol. 3, no. 5, pp. 224228, 2007.

[32] L. Vujanovic and L. H. Butterfield, "Melanoma cancer vaccines and anti-tumor T cell responses," Journal of Cellular Biochemistry, vol. 102, no. 2, pp. 301-310, 2007.

[33] S. J. van Vliet, J. J. García-Vallejo, and Y. Van Kooyk, "Dendritic cells and C-type lectin receptors: coupling innate to adaptive immune responses," Immunology and Cell Biology, vol. 86, no. 7, pp. 580-587, 2008.

[34] H. P. Vollmers and S. Brändlein, “Tumors: too sweet to remember?” Molecular Cancer, vol. 6, article 78, 2007.

[35] E. I. Buzás, B. György, M. Pásztói, I. Jelinek, A. Falus, and H.-J. Gabius, "Carbohydrate recognition systems in autoimmunity," Autoimmunity, vol. 39, no. 8, pp. 691-704, 2006.

[36] U. Galili, "Immune response, accomodation, and tolerance to transplantation carbohydrate antigens," Transplantation, vol. 78, no. 8, pp. 1093-1098, 2004.

[37] A. Weintraub, "Immunology of bacterial polysaccharide antigens," Carbohydrate Research, vol. 338, no. 23, pp. 25392547, 2003.

[38] B. A. 'T Hart and Y. van Kooyk, "Yin-Yang regulation of autoimmunity by DCs," Trends in Immunology, vol. 25, no. 7, pp. 353-359, 2004.

[39] M. H. Ravindranath, S. Muthugounder, M. R. Hannah, and D. L. Morton, "Significance of endogenous augmentation of antiganglioside IgM in cancer patients: potential tool for early detection and management of cancer therapy," Annals of the New York Academy of Sciences, vol. 1107, pp. 212-222, 2007. 
[40] B. A. Cobb and D. L. Kasper, "Coming of age: carbohydrates and immunity," European Journal of Immunology, vol. 35, no. 2, pp. 352-356, 2005.

[41] H. Wang and S. H. Clarke, "Regulation of B-cell development by antibody specificity," Current Opinion in Immunology, vol. 16, no. 2, pp. 246-250, 2004.

[42] J. B. Carey, C. S. Moffatt-Blue, L. C. Watson, A. L. Gavin, and A. J. Feeney, "Repertoire-based selection into the marginal zone compartment during B cell development," Journal of Experimental Medicine, vol. 205, no. 9, pp. 2043-2052, 2008.

[43] X.-J. Zhao and N.-K. V. Cheung, "GD2 oligosaccharide: target for cytotoxic T lymphocytes," Journal of Experimental Medicine, vol. 182, no. 1, pp. 67-74, 1995.

[44] M. V. Dhodapkar, "Harnessing human CD1d restricted T cells for tumor immunity: progress and challenges," Frontiers in Bioscience, vol. 14, pp. 796-807, 2009.

[45] B. A. Cobb, Q. Wang, A. O. Tzianabos, and D. L. Kasper, "Polysaccharide processing and presentation by the MHCII pathway," Cell, vol. 117, no. 5, pp. 677-687, 2004.

[46] A. M. Vlad, S. Muller, M. Cudic, et al., "Complex carbohydrates are not removed during processing of glycoproteins by dendritic cells: processing of tumor antigen MUC1 glycopeptides for presentation to major histocompatibility complex class II-restricted T cells," Journal of Experimental Medicine, vol. 196, no. 11, pp. 1435-1446, 2002.

[47] S. V. Evans, B. W. Sigurskjold, H. J. Jennings, et al., "Evidence for the extended helical nature of polysaccharide epitopes. The 2.8 A resolution structure and thermodynamics of ligand binding of an antigen binding fragment specific for $\alpha-(2 \rightarrow$ 8)-polysialic acid," Biochemistry, vol. 34 , no. 20, pp. $6737-$ 6744, 1995.

[48] C. Forestier, E. Moreno, S. Méresse, et al., "Interaction of Brucella abortus lipopolysaccharide with major histocompatibility complex class II molecules in B lymphocytes," Infection and Immunity, vol. 67, no. 8, pp. 4048-4054, 1999.

[49] A. O. Tzianabos, R. W. Finberg, Y. Wang, et al., "T cells activated by zwitterionic molecules prevent abscesses induced by pathogenic bacteria," Journal of Biological Chemistry, vol. 275, no. 10, pp. 6733-6740, 2000.

[50] Y. van Kooyk, A. Engering, A. N. Lekkerkerker, I. S. Ludwig, and T. B. H. Geijtenbeek, "Pathogens use carbohydrates to escape immunity induced by dendritic cells," Current Opinion in Immunology, vol. 16, no. 4, pp. 488-493, 2004.

[51] U. Galili, E. A. Rachmilewitz, A. Peleg, and I. Flechner, "A unique natural human IgG antibody with anti- $\alpha$-galactosyl specificity," Journal of Experimental Medicine, vol. 160, no. 5, pp. 1519-1531, 1984.

[52] U. Galili, R. E. Mandrell, R. M. Hamadeh, S. B. Shohet, and J. M. Griffiss, "Interaction between human natural anti- $\alpha$ galactosyl immunoglobulin G and bacteria of the human flora," Infection and Immunity, vol. 56, no. 7, pp. 1730-1737, 1988.

[53] I. M. MCmorrow, C. A. Comrack, D. H. Sachs, and H. DerSimonian, "Heterogeneity of human anti-pig natural antibodies cross-reactive with the $\operatorname{Gal}(\alpha 1,3)$ Galactose epitope," Transplantation, vol. 64, no. 3, pp. 501-510, 1997.

[54] N. Barreau, G. Blancho, C. Boulet, et al., "Natural anti-Gal antibodies constitute $0.2 \%$ of intravenous immunoglobulin and are equally retained on a synthetic disaccharide column or on an immobilized natural glycoprotein," Transplantation Proceedings, vol. 32, no. 5, pp. 882-883, 2000.

[55] M. Sæthre, U. Ø. Sølvik, G. Haraldsen, et al., "Human serum-induced porcine endothelial cell E-selectin expression is associated with IgG3 and IgM anti-Gal antibodies," Xenotransplantation, vol. 9, no. 5, pp. 350-358, 2002.

[56] J.-P. Dehoux, B. de la Parra, D. Latinne, H. Bazin, and P. Gianello, "Characterization of baboon anti-porcine IgG antibodies during acute vascular rejection of porcine kidney xenograft," Xenotransplantation, vol. 9, no. 5, pp. 338-349, 2002.

[57] W. D. Jin, T. Zhou, H. Zeng, et al., "Hyperacute rejection by anti-Gal IgG1, IgG2a, and IgG2b is dependent on complement and Fc- $\gamma$ receptors," Journal of Immunology, vol. 180, no. 1, pp. 261-268, 2008.

[58] U. Galili and D. C. LaTemple, "Natural anti-Gal antibody as a universal augmenter of autologous tumor vaccine immunogenicity," Immunology Today, vol. 18, no. 6, pp. 281285, 1997.

[59] U. Galili, "Interaction of the natural anti-Gal antibody with $\alpha$-galactosyl epitopes: a major obstacle for xenotransplantation in humans," Immunology Today, vol. 14, no. 10, pp. 480482, 1993.

[60] Y. Xu, A. Sette, J. Sidney, S. J. Gendler, and A. Franco, "Tumor-associated carbohydrate antigens: a possible avenue for cancer prevention," Immunology and Cell Biology, vol. 83, no. 4, pp. 440-448, 2005.

[61] M. F. Wolf, U. Koerner, B. Klumpp, and K. Schumacher, "Characterization of Thomsen-Friedenreich antibody subpopulations from normal human serum," Tumor Biology, vol. 8, no. 5, pp. 264-272, 1987.

[62] M. Zanetti, G. Lenert, and G. F. Springer, "Idiotypes of pre-existing human anti-carcinoma anti-T and anti-Tn antibodies," International Immunology, vol. 5, no. 2, pp. 113119, 1993.

[63] S. Hirohashi, H. Clausen, T. Yamada, Y. Shimosato, and S. Hakomori, "Blood group A cross-reacting epitope defined by monoclonal antibodies NCC-LU-35 and -81 expressed in cancer of blood group $\mathrm{O}$ or B individuals: its identification as Tn antigen," Proceedings of the National Academy of Sciences of the United States of America, vol. 82, no. 20, pp. 7039-7043, 1985.

[64] U. Galili, J. Buehler, S. B. Shohet, and B. A. Macher, "The human natural anti-Gal IgG. III. The subtlety of immune tolerance in man as demonstrated by crossreactivity between natural anti-Gal and anti-B antibodies," Journal of Experimental Medicine, vol. 165, no. 3, pp. 693-704, 1987.

[65] E. P. Smorodin, O. A. Kurtenkov, B. L. Sergeyev, K. E. Kodar, V. I. Chuzmarov, and V. P. Afanasyev, "Postoperative change of anti-Thomsen-Friedenreich and Tn IgG level: the followup study of gastrointestinal cancer patients," World Journal of Gastroenterology, vol. 14, no. 27, pp. 4352-4358, 2008.

[66] O. Kurtenkov, K. Klaamas, S. Mensdorff-Pouilly, L. Miljukhina, L. Shljapnikova, and V. Chužmarov, "Humoral immune response to MUC1 and to the ThomsenFriedenreich (TF) glycotope in patients with gastric cancer: relation to survival," Acta Oncologica, vol. 46, no. 3, pp. 316-323, 2007.

[67] G. F. Springer, "Immunoreactive $\mathrm{T}$ and $\mathrm{Tn}$ epitopes in cancer diagnosis, prognosis, and immunotherapy," Journal of Molecular Medicine, vol. 75, no. 8, pp. 594-602, 1997.

[68] F. R. Carbone and P. A. Gleeson, "Carbohydrates and antigen recognition by T cells," Glycobiology, vol. 7, no. 6, pp. 725730, 1997.

[69] C. A. Janeway Jr., B. E. Cohen, S. Z. Ben Sasson, and W. E. Paul, "The specificity of cellular immune responses in guinea pigs. I. T cells specific for 2,4 dinitrophenyl O tyrosyl 
residues," Journal of Experimental Medicine, vol. 141, no. 1, pp. 42-55, 1975.

[70] U. M. Abdel-Motal, L. Berg, A. Rosén, et al., "Immunization with glycosylated Kb-binding peptides generates carbohydrate-specific, unrestricted cytotoxic T cells," European Journal of Immunology, vol. 26, no. 3, pp. 544-551, 1996.

[71] E. Michaëlsson, J. Broddefalk, Å. Engström, J. Kihlberg, and R. Holmdahl, "Antigen processing and presentation of a naturally glycosylated protein elicits major histocompatibility complex class II-restricted, carbohydrate-specific T cells," European Journal of Immunology, vol. 26, no. 8, pp. 19061910, 1996.

[72] A. Franco, "CTL-based cancer preventive/therapeutic vaccines for carcinomas: role of tumour-associated carbohydrate antigens," Scandinavian Journal of Immunology, vol. 61, no. 5, pp. 391-397, 2005.

[73] L. Galli-Stampino, E. Meinjohanns, K. Frische, et al., "T-cell recognition of tumor-associated carbohydrates: the nature of the glycan moiety plays a decisive role in determining glycopeptide immunogenicity," Cancer Research, vol. 57, no. 15, pp. 3214-3222, 1997.

[74] A. Glithero, J. Tormo, J. S. Haurum, et al., "Crystal structures of two $\mathrm{H}-2 \mathrm{D}^{\mathrm{b}} /$ glycopeptide complexes suggest a molecular basis for CTL cross-reactivity," Immunity, vol. 10, no. 1, pp. 63-74, 1999.

[75] J. S. Haurum, G. Arsequell, A. C. Lellouch, et al., "Recognition of carbohydrate by major histocompatibility complex class I-restricted, glycopeptide-specific cytotoxic T lymphocytes," Journal of Experimental Medicine, vol. 180, no. 2, pp. 739-744, 1994.

[76] J. S. Haurum, L. Tan, G. Arsequell, et al., "Peptide anchor residue glycosylation: effect on class I major histocompatibility complex binding and cytotoxic $\mathrm{T}$ lymphocyte recognition," European Journal of Immunology, vol. 25, no. 12, pp. 3270-3276, 1995.

[77] T. Jensen, L. Galli-Stampino, S. Mouritsen, et al., "T cell recognition of Tn-glycosylated peptide antigens," European Journal of Immunology, vol. 26, no. 6, pp. 1342-1349, 1996.

[78] T. Jensen, P. Hansen, L. Galli-Stampino, et al., "Carbohydrate and peptide specificity of MHC class II-restricted T cell hybridomas raised against an O-glycosylated self peptide," Journal of Immunology, vol. 158, no. 8, pp. 3769-3778, 1997.

[79] I. B. Kastrup, S. Stevanovic, G. Arsequell, et al., "Lectin purified human class I MHC-derived peptides: evidence for presentation of glycopeptides in vivo," Tissue Antigens, vol. 56, no. 2, pp. 129-135, 2000.

[80] J. A. Speir, U. M. Abdel-Motal, M. Jondal, and I. A. Wilson, "Crystal structure of an MHC class I presented glycopeptide that generates carbohydrate-specific CTL," Immunity, vol. 10, no. 1, pp. 51-61, 1999.

[81] D. Stepensky, E. Tzehoval, E. Vadai, and L. Eisenbach, "Oglycosylated versus non-glycosylated MUC1-derived peptides as potential targets for cytotoxic immunotherapy of carcinoma," Clinical and Experimental Immunology, vol. 143, no. 1, pp. 139-149, 2006.

[82] Y. Xu, S. J. Gendler, and A. Franco, "Designer glycopeptides for cytotoxic T cell-based elimination of carcinomas," Journal of Experimental Medicine, vol. 199, no. 5, pp. 707-716, 2004.

[83] B. M. Sandmaier, D. V. Oparin, L. A. Holmberg, M. A. Reddish, G. D. MacLean, and B. M. Longenecker, "Evidence of a cellular immune response against sialyl-Tn in breast and ovarian cancer patients after high-dose chemotherapy, stem cell rescue, and immunization with Theratope STn-KLH cancer vaccine," Journal of Immunotherapy, vol. 22, no. 1, pp. 54-66, 1999.

[84] C. M. Böhm, M. C. Mulder, R. Zennadi, et al., "Carbohydrate recognition on MUC1-expressing targets enhances cytotoxicity of a T cell subpopulation," Scandinavian Journal of Immunology, vol. 46, no. 1, pp. 27-34, 1997.

[85] A. Franco, "Glycoconjugates as vaccines for cancer immunotherapy: clinical trials and future directions," Anti-Cancer Agents in Medicinal Chemistry, vol. 8, no. 1, pp. 86-91, 2008.

[86] V. Apostolopoulos, C. Osinski, and I. F. C. McKenzie, "MUC1 cross-reactive Gal $\alpha(1,3) \mathrm{Gal}$ antibodies in humans switch immune responses from cellular to humoral," Nature Medicine, vol. 4, no. 3, pp. 315-320, 1998.

[87] V. Apostolopoulos, M. S. Sandrin, and I. F. C. McKenzie, "Mimics and cross reactions of relevance to tumour immunotherapy," Vaccine, vol. 18, no. 3-4, pp. 268-275, 1999.

[88] G. D. MacLean, M. A. Reddish, R. R. Koganty, and B. M. Longenecker, "Antibodies against mucin-associated sialyl-Tn epitopes correlate with survival of metastatic adenocarcinoma patients undergoing active specific immunotherapy with synthetic STn vaccine," Journal of Immunotherapy, vol. 19, no. 1, pp. 59-68, 1996.

[89] M. S. Sandrin, H. A. Vaughan, P.-X. Xing, and I. F. C. McKenzie, "Natural human anti-Gal $\alpha(1,3) \mathrm{Gal}$ antibodies react with human mucin peptides," Glycoconjugate Journal, vol. 14, no. 1, pp. 97-105, 1997.

[90] B. Monzavi-Karbassi, G. Cunto-Amesty, P. Luo, A. Lees, and T. Kieber-Emmons, "Immunological characterization of peptide mimetics of carbohydrate antigens in vaccine design strategies," Biologicals, vol. 29, no. 3-4, pp. 249-257, 2001.

[91] B. Monzavi-Karbassi, P. Luo, F. Jousheghany, et al., "A mimic of tumor rejection antigen-associated carbohydrates mediates an antitumor cellular response," Cancer Research, vol. 64, no. 6, pp. 2162-2166, 2004.

[92] B. Monzavi-Karbassi, S. Shamloo, M. Kieber-Emmons, et al., "Priming characteristics of peptide mimotopes of carbohydrate antigens," Vaccine, vol. 21, no. 7-8, pp. 753-760, 2003.

[93] G. Cunto-Amesty, P. Luo, B. Monzavi-Karbassi, A. Lees, and T. Kieber-Emmons, "Exploiting molecular mimicry to broaden the immune response to carbohydrate antigens for vaccine development," Vaccine, vol. 19, no. 17-19, pp. 23612368, 2001.

[94] T. Kottke, J. Pulido, J. Thompson, et al., "Antitumor immunity can be uncoupled from autoimmunity following heat shock protein 70-mediated inflammatory killing of normal pancreas," Cancer Research, vol. 69, no. 19, pp. 7767-7774, 2009.

[95] K. L. Knutson and M. L. Disis, "Tumor antigen-specific $\mathrm{T}$ helper cells in cancer immunity and immunotherapy," Cancer Immunology, Immunotherapy, vol. 54, no. 8, pp. 721728, 2005.

[96] K. Hung, R. Hayashi, A. Lafond-Walker, C. Lowenstein, D. Pardoll, and H. Levitsky, "The central role of $\mathrm{CD}^{+} \mathrm{T}$ cells in the antitumor immune response," Journal of Experimental Medicine, vol. 188, no. 12, pp. 2357-2368, 1998.

[97] R.-F. Wang, "The role of MHC class II-restricted tumor antigens and $\mathrm{CD}^{+} \mathrm{T}$ cells in antitumor immunity," Trends in Immunology, vol. 22, no. 5, pp. 269-276, 2001.

[98] A. M. Livingstone, E. B. Wilson, F. Ontiveros, and J.-C.E. Wang, "Unravelling the mechanisms of help for $\mathrm{CD} 8^{+} \mathrm{T}$ cell responses," Immunologic Research, vol. 45, no. 2-3, pp. 209217, 2009. 
[99] C. A. Black, "Delayed type hypersensitivity: current theories with an historic perspective," Dermatology Online Journal, vol. 5, no. 1, p. 7, 1999.

[100] M. Osorio, E. Gracia, E. Rodríguez, et al., "Heterophilic NeuGcGM3 ganglioside cancer vaccine in advanced melanoma patients: results of a Phase Ib/IIa study," Cancer Biology and Therapy, vol. 7, no. 4, pp. 488-495, 2008.

[101] S. K. Kim, G. Ragupathi, S. Cappello, E. Kagan, and P. O. Livingston, "Effect of immunological adjuvant combinations on the antibody and T-cell response to vaccination with MUC1-KLH and GD3-KLH conjugates," Vaccine, vol. 19, no. 4-5, pp. 530-537, 2000.

[102] M. H. Ravindranath, P. M. Bauer, A. A. Amiri, et al., "Cellular cancer vaccine induces delayed-type hypersensitivity reaction and augments antibody response to tumor-associated carbohydrate antigens (sialyl Lea, sialyl Lex, GD3 and GM2) better than soluble lysate cancer vaccine," Anti-Cancer Drugs, vol. 8, no. 3, pp. 217-224, 1997.

[103] P. Puccetti, R. Bianchi, L. Romani, E. Cenci, and M. C. Fioretti, "Delayed-type hypersensitivity to tumor antigens co-expressed with immunogenic determinants induced by xenogenization," International Journal of Cancer, vol. 43, no. 2, pp. 279-284, 1989.

[104] E. Kuramoto, N. Watanabe, D. Iwata, O. Yano, S. Shimada, and T. Tokunaga, "Changes of host cell infiltration into Meth A fibrosarcoma tumor during the course of regression induced by injections of a BCG nucleic acid fraction," International Journal of Immunopharmacology, vol. 14, no. 5, pp. 773-782, 1992.

[105] M. Szczepanik, M. Akahira-Azuma, K. Bryniarski, et al., "B-1 B cells mediate required early $\mathrm{T}$ cell recruitment to elicit protein-induced delayed-type hypersensitivity," Journal of Immunology, vol. 171, no. 11, pp. 6225-6235, 2003.

[106] R. F. Tsuji, M. Szczepanik, I. Kawikova, et al., "B celldependent $\mathrm{T}$ cell responses: IgM antibodies are required to elicit contact sensitivity," Journal of Experimental Medicine, vol. 196, no. 10, pp. 1277-1290, 2002.

[107] H. Schreiber, T. H. Wu, J. Nachman, and D. A. Rowley, "Immunological enhancement of primary tumor development and its prevention," Seminars in Cancer Biology, vol. 10, no. 5, pp. 351-357, 2000.

[108] H. P. Vollmers and S. Brändlein, "The "early birds": natural IgM antibodies and immune surveillance," Histology and Histopathology, vol. 20, no. 3, pp. 927-937, 2005.

[109] G. Dighiero, P. Lymberi, D. Holmberg, et al., "High frequency of natural autoantibodies in normal newborn mice," Journal of Immunology, vol. 134, no. 2, pp. 765-771, 1985.

[110] J. Gil, R. Alvarez, J. E. Vinuela, et al., "Inhibition of in vivo tumor growth by a monoclonal IgM antibody recognizing tumor cell surface carbohydrates," Cancer Research, vol. 50, no. 22, pp. 7301-7306, 1990.

[111] X. Zhong, W. Gao, N. Degauque, et al., "Reciprocal generation of Th1/Th17 and $\mathrm{T}_{\text {reg }}$ cells by B1 and B2 B cells," European Journal of Immunology, vol. 37, no. 9, pp. 24002404, 2007.

[112] M. Croft and S. L. Swain, "Analysis of $\mathrm{CD}^{+} \mathrm{T}$ cells that provide contact-dependent bystander help to B cells," Journal of Immunology, vol. 149, no. 10, pp. 3157-3165, 1992.

[113] B. Monzavi-Karbassi, L. J. Hennings, C. Artaud, et al., "Preclinical studies of carbohydrate mimetic peptide vaccines for breast cancer and melanoma," Vaccine, vol. 25, no. 16, pp. 3022-3031, 2007.

[114] A. Wondimu, T. Zhang, T. Kieber-Emmons, et al., "Peptides mimicking GD2 ganglioside elicit cellular, humoral and tumor-protective immune responses in mice," Cancer Immunology, Immunotherapy, vol. 57, no. 7, pp. 1079-1089, 2008.

[115] Y. D. Dai, G. Carayanniotis, and E. Sercarz, "Antigen processing by autoreactive B cells promotes determinant spreading," Cellular \& Molecular Immunology, vol. 2, no. 3, pp. 169-175, 2005.

[116] S. Deola, M. C. Panelli, D. Maric, et al., "Helper B cells promote cytotoxic $\mathrm{T}$ cell survival and proliferation independently of antigen presentation through CD27/CD70 interactions," Journal of Immunology, vol. 180, no. 3, pp. 1362-1372, 2008.

[117] P. W. Askenase, "Yes T cells, but three different T cells ( $\alpha \beta$, $\gamma \sigma$ and NK T cells), and also B-1 cells mediate contact sensitivity," Clinical and Experimental Immunology, vol. 125, no. 3, pp. 345-350, 2001.

[118] T. Matsushita, K. Yanaba, J.-D. Bouaziz, M. Fujimoto, and T. F. Tedder, "Regulatory B cells inhibit EAE initiation in mice while other B cells promote disease progression," Journal of Clinical Investigation, vol. 118, no. 10, pp. 3420-3430, 2008.

[119] T. Matsushita, "Immunological memory," Advances in Immunology, vol. 53, pp. 217-265, 2008.

[120] A. F. Ochsenbein and R. M. Zinkernagel, "Natural antibodies and complement link innate and acquired immunity," Immunology Today, vol. 21, no. 12, pp. 624-630, 2000.

[121] M. E. Youd, A. R. Ferguson, and R. B. Corley, "Synergistic roles of $\operatorname{IgM}$ and complement in antigen trapping and follicular localization," European Journal of Immunology, vol. 32, no. 8, pp. 2328-2337, 2002.

[122] H. Von Boehmer, I. Aifantis, F. Gounari, et al., "Thymic selection revisited: how essential is it?" Immunological Reviews, vol. 191, pp. 62-78, 2003.

[123] M.-L. Lin, Y. Zhan, J. A. Villadangos, and A. M. Lew, “The cell biology of cross-presentation and the role of dendritic cell subsets," Immunology and Cell Biology, vol. 86, no. 4, pp. 353-362, 2008.

[124] M. J. Bevan, "Cross priming for a secondary cytotoxic respsonse to minor $\mathrm{H}$ antigens with $\mathrm{H}-2$ congenic cells which do not cross react in the cytotoxic assay," Journal of Experimental Medicine, vol. 143, no. 5, pp. 1283-1288, 1976.

[125] A. Heit, F. Schmitz, M. O'Keeffe, et al., "Protective CD8 T cell immunity triggered by $\mathrm{CpG}$-protein conjugates competes with the efficacy of live vaccines," Journal of Immunology, vol. 174, no. 7, pp. 4373-4380, 2005.

[126] J. B. Ulmer, R. R. Deck, C. M. Dewitt, J. J. Donnelly, and M. A. Liu, "Generation of MHC class I-restricted cytotoxic T lymphocytes by expression of a viral protein in muscle cells: antigen presentation by non-muscle cells," Immunology, vol. 89, no. 1, pp. 59-67, 1996.

[127] J. S. Boyle, C. Koniaras, and A. M. Lew, "Influence of cellular location of expressed antigen on the efficacy of DNA vaccination: cytotoxic $\mathrm{T}$ lymphocyte and antibody responses are suboptimal when antigen is cytoplasmic after intramuscular DNA immunization," International Immunology, vol. 9, no. 12, pp. 1897-1906, 1997.

[128] A. Murshid, J. Gong, and S. K. Calderwood, "Heatshock proteins in cancer vaccines: agents of antigen crosspresentation," Expert Review of Vaccines, vol. 7, no. 7, pp. 1019-1030, 2008.

[129] K. Shimizu, Y. Kurosawa, M. Taniguchi, R. M. Steinman, and S.-I. Fujii, "Cross-presentation of glycolipid from tumor cells loaded with $\alpha$-galactosylceramide leads to potent and longlived T cell-mediated immunity via dendritic cells," Journal of Experimental Medicine, vol. 204, no. 11, pp. 2641-2653, 2007. 
[130] D. Valmori, N. E. Souleimanian, V. Tosello, et al., "Vaccination with NY-ESO-1 protein and CpG in Montanide induces integrated antibody/Th1 responses and CD8 T cells through cross-priming," Proceedings of the National Academy of Sciences of the United States of America, vol. 104, no. 21, pp. 8947-8952, 2007.

[131] C. H. Qiu, Y. Miyake, H. Kaise, H. Kitamura, O. Ohara, and M. Tanaka, "Novel subset of $\mathrm{CD} 8_{\alpha}{ }^{+}$dendritic cells localized in the marginal zone is responsible for tolerance to cellassociated antigens," Journal of Immunology, vol. 182, no. 7, pp. 4127-4136, 2009.

[132] S. O. Harbers, A. Crocker, G. Catalano, et al., "Antibodyenhanced cross-presentation of self antigen breaks $\mathrm{T}$ cell tolerance," Journal of Clinical Investigation, vol. 117, no. 5, pp. 1361-1369, 2007.

[133] T. A. Ferguson, J. Herndon, B. Elzey, T. S. Griffith, S. Schoenberger, and D. R. Green, "Uptake of apoptotic antigencoupled cells by lymphoid dendritic cells and cross-priming of $\mathrm{CD}^{+} \mathrm{T}$ cells produce active immune unresponsiveness," Journal of Immunology, vol. 168, no. 11, pp. 5589-5595, 2002.

[134] S. Freigang, D. Egger, K. Bienz, H. Hengartner, and R. M. Zinkernagel, "Endogenous neosynthesis vs. crosspresentation of viral antigens for cytotoxic T cell priming," Proceedings of the National Academy of Sciences of the United States of America, vol. 100, no. 23, pp. 13477-13482, 2003.

[135] R. M. Zinkernagel, "On cross-priming of MHC class Ispecific CTL: rule or exception?" European Journal of Immunology, vol. 32, no. 9, pp. 2385-2392, 2002.

[136] A. Knuth, B. Danowski, H. F. Oettgen, and L. J. Old, "T-cell-mediated cytotoxicity against autologous malignant melanoma: analysis with interleukin 2-dependent T-cell cultures," Proceedings of the National Academy of Sciences of the United States of America, vol. 81, no. 11, pp. 3511-3515, 1984.

[137] T. M. Kundig, M. F. Bachmann, L. Lefrancois, L. Puddington, H. Hengartner, and R. M. Zinkernagel, "Nonimmunogenic tumor cells may efficiently restimulate tumor antigenspecific cytotoxic T cells," Journal of Immunology, vol. 150, no. 10, pp. 4450-4456, 1993.

[138] D. J. Schendel, B. Gansbacher, R. Oberneder, et al., "Tumorspecific lysis of human renal cell carcinomas by tumorinfiltrating lymphocytes: I. HLA-A2-restricted recognition of autologous and allogeneic tumor lines," Journal of Immunology, vol. 151, no. 8, pp. 4209-4220, 1993.

[139] M. Schnurr, P. Galambos, C. Scholz, et al., "Tumor cell lysate-pulsed human dendritic cells induce a T-cell response against pancreatic carcinoma cells: an in vitro model for the assessment of tumor vaccines," Cancer Research, vol. 61, no. 17, pp. 6445-6450, 2001.

[140] P. A. Würtzen, L. $\varnothing$. Pedersen, H. S. Poulsen, and M. H. Claesson, "Specific killing of p53 mutated tumor cell lines by a cross-reactive human HLA-A2-restricted p53-specific CTL line," International Journal of Cancer, vol. 93, no. 6, pp. 855$861,2001$.

[141] K. M. Zirlik, D. Zahrieh, D. Neuberg, and J. G. Gribben, "Cytotoxic T cells generated against heteroclitic peptides kill primary tumor cells independent of the binding affinity of the native tumor antigen peptide," Blood, vol. 108, no. 12, pp. 3865-3870, 2006.

[142] B. Wang, J. M. Y. Kuroiwa, L.-Z. He, A. Charalambous, T. Keler, and R. M. Steinman, "The human cancer antigen mesothelin is more efficiently presented to the mouse immune system when targeted to the DEC-205/CD205 receptor on dendritic cells," Annals of the New York Academy of Sciences, vol. 1174, pp. 6-17, 2009.

[143] U. Galili, "Autologous tumor vaccines processed to express $\alpha$-gal epitopes: a practical approach to immunotherapy in cancer," Cancer Immunology, Immunotherapy, vol. 53, no. 11, pp. 935-945, 2004.

[144] I. F. Hermans, D. S. Ritchie, J. Yang, J. M. Roberts, and F. Ronchese, "CD8 ${ }^{+} \mathrm{T}$ cell-dependent elimination of dendritic cells in vivo limits the induction of antitumor immunity," Journal of Immunology, vol. 164, no. 6, pp. 3095-3101, 2000.

[145] D. C. Kilpatrick, "Animal lectins: a historical introduction and overview," Biochimica et Biophysica Acta, vol. 1572, no. 2-3, pp. 187-197, 2002.

[146] L. East and C. M. Isacke, "The mannose receptor family," Biochimica et Biophysica Acta, vol. 1572, no. 2-3, pp. 364-386, 2002.

[147] R. E. Shrimpton, M. Butler, A.-S. Morel, E. Eren, S. S. Hue, and M. A. Ritter, "CD205 (DEC-205): a recognition receptor for apoptotic and necrotic self," Molecular Immunology, vol. 46, no. 6, pp. 1229-1239, 2009.

[148] S. Burgdorf, V. Lukacs-Kornek, and C. Kurts, "The mannose receptor mediates uptake of soluble but not of cell-associated antigen for cross-presentation," Journal of Immunology, vol. 176, no. 11, pp. 6770-6776, 2006.

[149] V. Ramakrishna, J. F. Treml, L. Vitale, et al., "Mannose receptor targeting of tumor antigen pmell7 to human dendritic cells directs anti-melanoma $\mathrm{T}$ cell responses via multiple HLA molecules," Journal of Immunology, vol. 172, no. 5, pp. 2845-2852, 2004.

[150] L.-Z. He, A. Crocker, J. Lee, et al., "Antigenic targeting of the human mannose receptor induces tumor immunity," Journal of Immunology, vol. 178, no. 10, pp. 6259-6267, 2007.

[151] S. Dasgupta, A.-M. Navarrete, J. Bayry, et al., "A role for exposed mannosylations in presentation of human therapeutic self-proteins to $\mathrm{CD} 4^{+} \mathrm{T}$ lymphocytes," Proceedings of the National Academy of Sciences of the United States of America, vol. 104, no. 21, pp. 8965-8970, 2007.

[152] M. Chieppa, G. Bianchi, A. Doni, et al., "Cross-linking of the mannose receptor on monocyte-derived dendritic cells activates an anti-inflammatory immunosuppressive program," Journal of Immunology, vol. 171, no. 9, pp. 4552-4560, 2003.

[153] J. Idoyaga, C. Cheong, K. Suda, et al., "Cutting edge: langerin/CD207 receptor on dendritic cells mediates efficient antigen presentation on MHC I and II products in vivo," Journal of Immunology, vol. 180, no. 6, pp. 3647-3650, 2008.

[154] S. K. Singh, J. Stephani, M. Schaefer, et al., "Targeting glycan modified OVA to murine DC-SIGN transgenic dendritic cells enhances MHC class I and II presentation," Molecular Immunology, vol. 47, no. 2-3, pp. 164-174, 2009.

[155] K. Takahara, Y. Omatsu, Y. Yashima, et al., "Identification and expression of mouse Langerin (CD207) in dendritic cells," International Immunology, vol. 14, no. 5, pp. 433-444, 2002.

[156] I. van Die, S. J. van Vliet, A. K. Nyame, et al., "The dendritic cell-specific C-type lectin DC-SIGN is a receptor for Schistosoma mansoni egg antigens and recognizes the glycan antigen Lewis x," Glycobiology, vol. 13, no. 6, pp. 471478, 2003.

[157] C. Galustian, C. G. Park, W. Chai, et al., "High and low affinity carbohydrate ligands revealed for murine SIGN-R1 by carbohydrate array and cell binding approaches, and differing specificities for SIGN-R3 and langerin," International Immunology, vol. 16, no. 6, pp. 853-866, 2004.

[158] B. Monzavi-Karbassi, P. Luo, G. Cunto-Amesty, et al., "Fucosylated lactosamines participate in adhesion of HIV-1 
envelope glycoprotein to dendritic cells," Archives of Virology, vol. 149, no. 1, pp. 75-91, 2004.

[159] M. Ujita, H. Nagayama, S. Kanie, et al., "Carbohydrate binding specificity of recombinant human macrophage $\beta$ glucan receptor dectin-1," Bioscience, Biotechnology and Biochemistry, vol. 73, no. 1, pp. 237-240, 2009.

[160] G. Ferwerda, F. Meyer-Wentrup, B.-J. Kullberg, M. G. Netea, and G. J. Adema, "Dectin-1 synergizes with TLR2 and TLR4 for cytokine production in human primary monocytes and macrophages," Cellular Microbiology, vol. 10, no. 10, pp. 2058-2066, 2008.

[161] S. Dillon, S. Agrawal, K. Banerjee, et al., "Yeast zymosan, a stimulus for TLR2 and dectin-1, induces regulatory antigenpresenting cells and immunological tolerance," Journal of Clinical Investigation, vol. 116, no. 4, pp. 916-928, 2006.

[162] P. Hernanz-Falcón, O. Joffre, D. L. Williams, and C. Reis e Sousa, "Internalization of dectin-1 terminates induction of inflammatory responses," European Journal of Immunology, vol. 39, no. 2, pp. 507-513, 2009.

[163] M. M. Weck, S. Appel, D. Werth, et al., "HDectin-1 is involved in uptake and cross-presentation of cellular antigens," Blood, vol. 111, no. 8, pp. 4264-4272, 2008.

[164] D. Sancho, D. Mourão-Sá, O. P. Joffre, et al., "Tumor therapy in mice via antigen targeting to a novel, DC-restricted C-type lectin," Journal of Clinical Investigation, vol. 118, no. 6, pp. 2098-2110, 2008.

[165] D. Sancho, O. P. Joffre, A. M. Keller, et al., "Identification of a dendritic cell receptor that couples sensing of necrosis to immunity," Nature, vol. 458, no. 7240, pp. 899-903, 2009.

[166] K. Mahnke, Y. Qian, J. Knop, and A. H. Enk, "Induction of $\mathrm{CD} 4^{+} / \mathrm{CD} 25^{+}$regulatory $\mathrm{T}$ cells by targeting of antigens to immature dendritic cells," Blood, vol. 101, no. 12, pp. 48624869, 2003.

[167] M. Cohn, "A rationalized set of default postulates that permit a coherent description of the immune system amenable to computer modeling," Scandinavian Journal of Immunology, vol. 68, no. 4, pp. 371-380, 2008.

[168] T. Moore, C. O. Ekworomadu, F. O. Eko, et al., "Fc receptormediated antibody regulation of $\mathrm{T}$ cell immunity against intracellular pathogens," Journal of Infectious Diseases, vol. 188, no. 4, pp. 617-624, 2003.

[169] A. Casadevall and L. Pirofski, "Insights into mechanisms of antibody-mediated immunity from studies with Cryptococcus neoformans," Current Molecular Medicine, vol. 5, no. 4, pp. 421-433, 2005.

[170] J. M. M. den Haan and M. J. Bevan, "Constitutive versus activation-dependent cross-presentation of immune complexes by $\mathrm{CD}^{+}$and $\mathrm{CD} 8^{-}$dendritic cells in vivo," Journal of Experimental Medicine, vol. 196, no. 6, pp. 817-827, 2002.

[171] K. M. Dhodapkar, J. Krasovsky, B. Williamson, and M. V. Dhodapkar, "Antitumor monoclonal antibodies enhance cross-presentation of cellular antigens and the generation of myeloma-specific killer T cells by dendritic cells," Journal of Experimental Medicine, vol. 195, no. 1, pp. 125-133, 2002.

[172] A. Dürrbach, E. Baple, A. F. Preece, B. Charpentier, and K. Gustafsson, "Virus recognition by specific natural antibodies and complement results in MHC I cross-presentation," European Journal of Immunology, vol. 37, no. 5, pp. 12541265, 2007.

[173] N. van Montfoort, J. M. H. de Jong, D. H. Schuurhuis, et al., "A novel role of complement factor $\mathrm{Clq}$ in augmenting the presentation of antigen captured in immune complexes to CD8 ${ }^{+}$T lymphocytes," Journal of Immunology, vol. 178, no. 12, pp. 7581-7586, 2007.
[174] K. Rafiq, A. Bergtold, and R. Clynes, "Immune complexmediated antigen presentation induces tumor immunity," Journal of Clinical Investigation, vol. 110, no. 1, pp. 71-79, 2002.

[175] Y. Liu, X. Gao, E. Masuda, P. B. Redecha, M. C. Blank, and L. Pricop, "Regulated expression of Fc $\gamma \mathrm{R}$ in human dendritic cells controls cross-presentation of antigen-antibody complexes," Journal of Immunology, vol. 177, no. 12, pp. 84408447, 2006.

[176] F. Nimmerjahn and J. V. Ravetch, "Antibodies, Fc receptors and cancer," Current Opinion in Immunology, vol. 19, no. 2, pp. 239-245, 2007.

[177] F. Nimmerjahn and J. V. Ravetch, "Immunology: divergent immunoglobulin G subclass activity through selective Fc receptor binding," Science, vol. 310, no. 5753, pp. 1510-1512, 2005.

[178] A. Wierzbicki, M. Gil, M. Ciesielski, et al., "Immunization with a mimotope of GD2 ganglioside induces $\mathrm{CD}^{+} \mathrm{T}$ cells that recognize cell adhesion molecules on tumor cells," Journal of Immunology, vol. 181, no. 9, pp. 6644-6653, 2008.

[179] C. Ding, L. Wang, J. Marroquin, and J. Yan, "Targeting of antigens to B cells augments antigen-specific T-cell responses and breaks immune tolerance to tumor-associated antigen MUC1," Blood, vol. 112, no. 7, pp. 2817-2825, 2008.

[180] K. R. Jerome, N. Domenech, and O. J. Finn, "Tumorspecific cytotoxic $\mathrm{T}$ cell clones from patients with breast and pancreatic adenocarcinoma recognize EBV-immortalized B cells transfected with polymorphic epithelial mucin complementary DNA," Journal of Immunology, vol. 151, no. 3, pp. 1654-1662, 1993.

[181] J. Taylor-Papadimitriou and O. J. Finn, "Biology, biochemistry and immunology of carcinoma-associated mucins," Immunology Today, vol. 18, no. 3, pp. 105-107, 1997.

[182] G. Denton, M. Sekowski, and M. R. Price, "Induction of antibody responses to breast carcinoma associated mucins using synthetic peptide constructs as immunogens," Cancer Letters, vol. 70, no. 3, pp. 143-150, 1993.

[183] L.-G. Yu, J. D. Milton, D. G. Fernig, and J. M. Rhodes, "Opposite effects on human colon cancer cell proliferation of two dietary Thomse-Friedenreich antigen-binding lectins," Journal of Cellular Physiology, vol. 186, no. 2, pp. 282-287, 2001.

[184] F. J. Irazoqui, B. Jansson, P. H. H. Lopez, and G. A. Nores, "Correlative fine specificity of several Thomsen-Friedenreich disaccharide-binding proteins with an effect on tumor cell proliferation," Journal of Biochemistry, vol. 130, no. 1, pp. 3337, 2001.

[185] V. Apostolopoulos, V. Karanikas, J. S. Haurum, and I. F. C. McKenzie, "Induction of HLA-A2-restricted CTLs to the mucin 1 human breast cancer antigen," Journal of Immunology, vol. 159, no. 11, pp. 5211-5218, 1997.

[186] B. J. Hebeis, K. Klenovsek, P. Rohwer, et al., "Activation of virus-specific memory B cells in the absence of T cell help," Journal of Experimental Medicine, vol. 199, no. 4, pp. 593602, 2004.

[187] B. Peters, J. Sidney, P. Bourne, et al., "The immune epitope database and analysis resource: from vision to blueprint," PLoS Biology, vol. 3, no. 3, article e91, 2005.

[188] M. Moutaftsi, B. Peters, V. Pasquetto, et al., "A consensus epitope prediction approach identifies the breadth of murine TCD8 ${ }^{+}$-cell responses to vaccinia virus," Nature Biotechnology, vol. 24, no. 7, pp. 817-819, 2006.

[189] C. Lundegaard, K. Lamberth, M. Harndahl, S. Buus, O. Lund, and M. Nielsen, "NetMHC-3.0: accurate web accessible 
predictions of human, mouse and monkey MHC class I affinities for peptides of length 8-11," Nucleic Acids Research, vol. 36, web server issue, pp. W509-W512, 2008.

[190] A. S. De Groot, J. McMurry, and L. Moise, "Prediction of immunogenicity: in silico paradigms, ex vivo and in vivo correlates," Current Opinion in Pharmacology, vol. 8, no. 5, pp. 620-626, 2008.

[191] A. S. De Groot, L. Moise, J. A. McMurry, et al., "Activation of natural regulatory $\mathrm{T}$ cells by $\mathrm{IgG}$ Fc-derived peptide “Tregitopes"," Blood, vol. 112, no. 8, pp. 3303-3311, 2008.

[192] F. Rahbarizadeh, M. J. Rasaee, M. Forouzandeh, et al., "The production and characterization of novel heavy-chain antibodies against the tandem repeat region of MUC1 mucin," Immunological Investigations, vol. 34, no. 4, pp. 431452, 2005.

[193] M. V. Croce, M. T. Isla-Larrain, A. Capafons, M. R. Price, and A. Segal-Eiras, "Humoral immune response induced by the protein core of MUC1 mucin in pregnant and healthy women," Breast Cancer Research and Treatment, vol. 69, no. 1, pp. 1-11, 2001. 


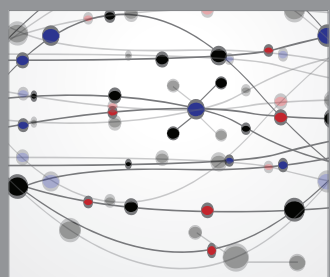

The Scientific World Journal
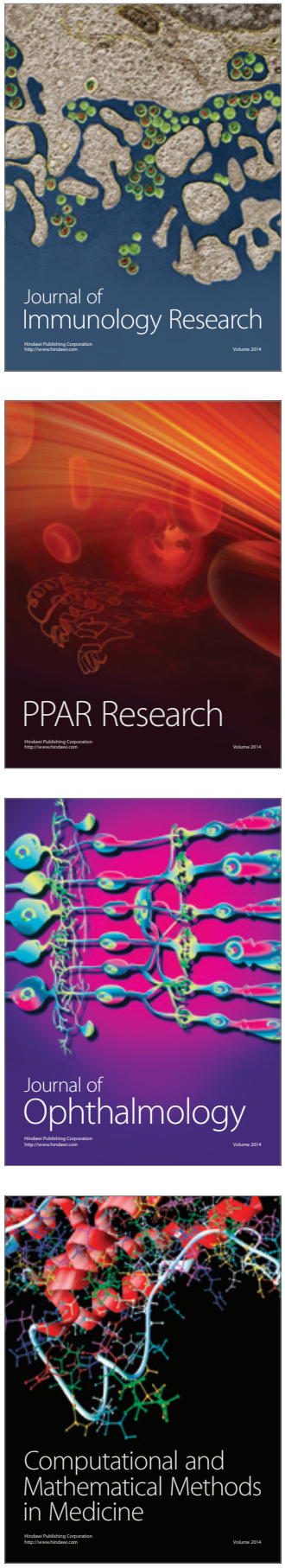

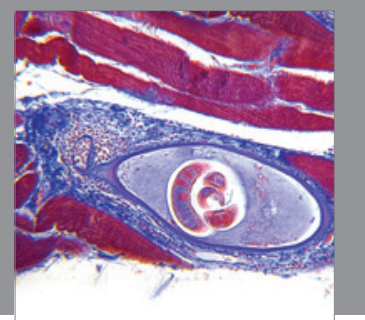

Gastroenterology

Research and Practice
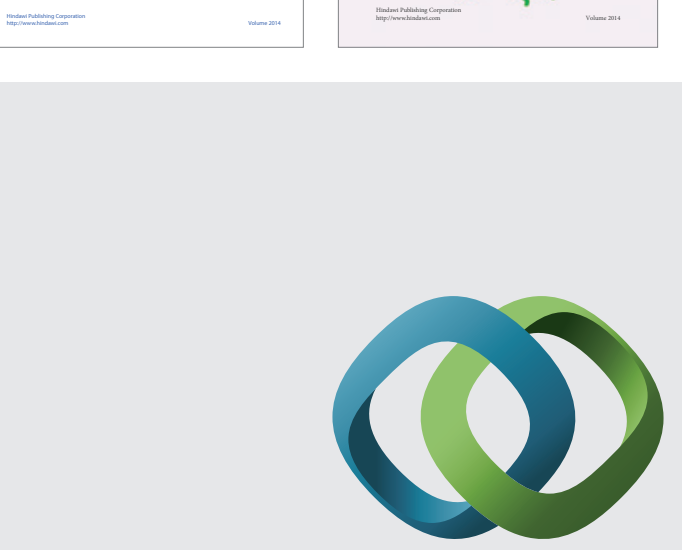

\section{Hindawi}

Submit your manuscripts at

http://www.hindawi.com
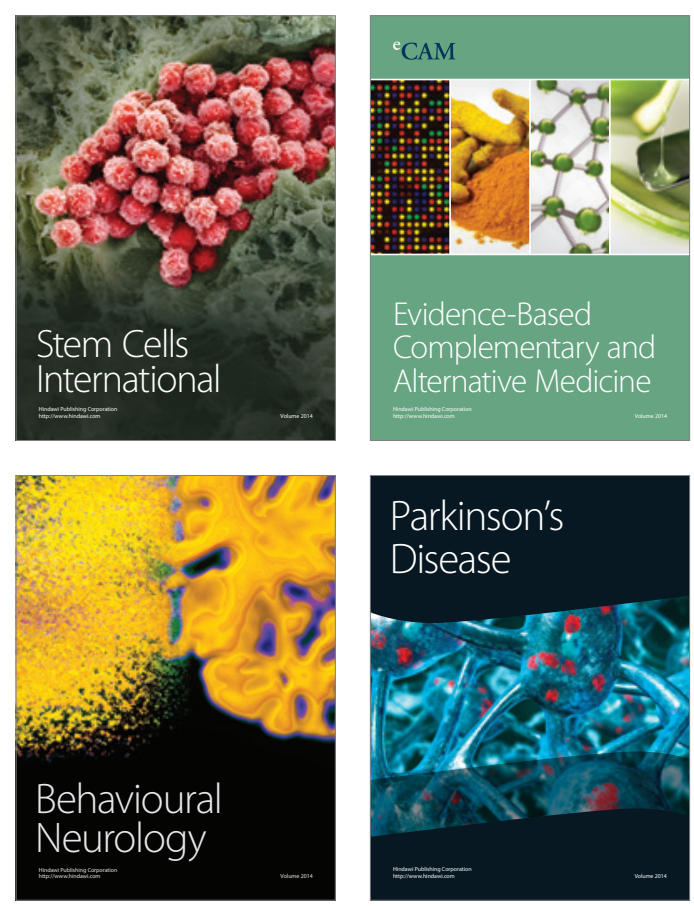

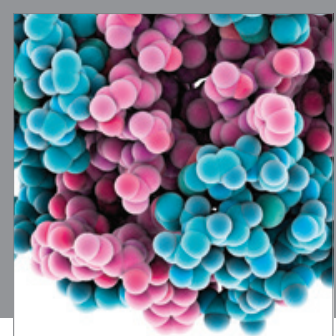

Journal of
Diabetes Research

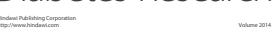

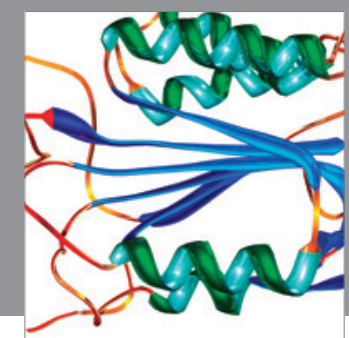

Disease Markers
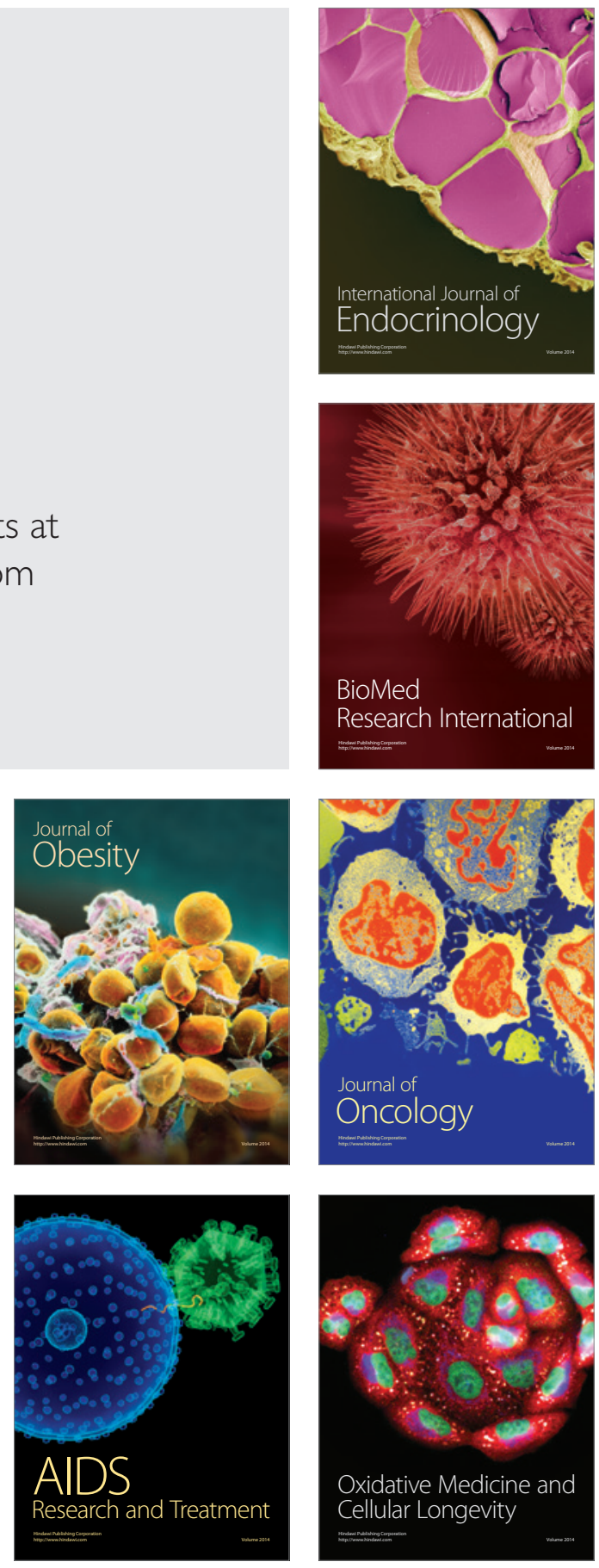